Sousa Jabbour, A. B. L., Vazquez-Brust, D., Jabbour, C. J. C., \& Latan, H. (2017). Green supply chain practices and environmental performance in Brazil: Survey, case studies, and implications for B2B. Industrial Marketing Management, 66, 13-28.

https://doi.org/10.1016/j.indmarman.2017.05.003 
Green supply chain practices and environmental performance in Brazil: survey, case studies, and implications for $\mathrm{B} 2 \mathrm{~B}$

Dr. Ana Beatriz Lopes de Sousa JABBOUR $(a, c)$ ana.jabbour@strath.ac.uk

Dr. Diego VAZQUEZ-BRUST (d)

E-mail: diego.vazquez-brust@port.ac.uk

Dr. Charbel José Chiappetta JABBOUR $(a, b) \quad * * * * *$ author for contact

c.j.chiappettajabbour@stir.ac.uk

Dr. Hengky LATAN $(e, f)$

hengkylatan@yahoo.com

(a)

UNESP - Sao Paulo State Univ, Bauru Campus

Av. Eng. L. Ed. C. Coube, 14-01, FEB-DEP, Bauru, Sao Paulo State, Brazil

17033360, Phone/Fax: 551431036122

(b)

University of Stirling, Stirling Management School

Centre for Advanced Education Management

Stirling FK9 4LA, Scotland, UK

Phone/Fax 01786473171

(c)

University of Strathclyde, Glasgow

Faculty of Engineering, DMEM

75 Montrose St, Glasgow G1 1XJ

Phone/Fax 01415482091

(d)

University of Portsmouth

Portsmouth Business School

Portland St, Portsmouth PO1 3DE

UK

(e) University of Pattimura,

Economic and Accounting Department,

(f) Universitas Diponegoro, Indonesia

Indonesia 


\title{
Green supply chain practices and environmental performance in Brazil: survey, case studies, and implications for B2B
}

\begin{abstract}
This article examines whether or not customers cooperate on organisations' environmental performance, in what circumstances it happens; and how customers can collaborate with organisations in order to they improve their environmental performance. This research uses both Ecological Modernisation (EM) and the Resource Dependence Theory (RDT) to analyse the effects of external Green Supply Chain Management (GSCM) practices, namely, 'Cooperation with Customers' (CC) and 'Green Purchasing' (GP) on the Environmental Performance (EP) of organisations. A multi-method model of research is used, combining a survey and multiple-case studies of Brazilian organisations. The main results and contributions of this research include: (a) the Brazilian setting, in the context of EM, which provides incentives for adopting GSCM practices, especially CC practices; (b) Brazilian organisations depend more on customers than on suppliers to improve EP; and (c) a matrix for a better understanding of the roles of suppliers and customers to achieve a better EP through a GSCM approach is proposed. This paper provides an extension to the EM and RDT theories applied to green operations management by showing that external GSCM can improve EP and that such a process depends more on CC than GP. Implications for B2B are highlighted.

Key words: Green supply chain management, cooperation with customers, resource dependence theory, ecological modernisation, sustainability, Brazil.
\end{abstract}

\section{Introduction}

National Geographic and global research consultancy GlobeScan developed an index to measure sustainable consumption behaviour (National Geographic, 2016). According to the latest survey, which was conducted in 18 countries in 2014, it was found that concern for environmental issues has increased since 2012 and developing countries are more likely to pursue sustainable consumption habits. India, China, South Korea, and Brazil are at the top of the list of more sustainable consumers.

The literature highlights that environmental pressure from stakeholders has increased, especially due to the awareness of customers. In general, the literature reviews both influences from end customers' (clients) environmental preferences on organisations' environmental initiatives (Nouira et al., 2016; Coskun et al., 2016; Kim, Park \& Swink, 2014) and the impact of customers as institutional pressure to induce organisations to improve their environmental performance (Lai et al., 2012; Gualandris \& Kalchschmidt, 2014). Conversely, the academic literature overwhelmingly focuses on green supplier selection practice (e.g. Darnall et al., 2008; Hsu \& Hu, 2008; Nawrocka et al., 2009; Arimura et al., 2011; Tate et al., 2014; Bhattacharya et al., 2014), or on cooperation in supply chains, focusing particularly on suppliers' cooperation (e.g. Woo et al., 2016; Ramanathan, Bentley \& Pang, 2014); whereas research on collaboration with customers is scarce.

Thus, since sustainable consumption behaviour has arisen, a reasonable hypothesis is that customers would be more willing to cooperate with organisations in terms of green operations, for instance, green packaging. Accordingly, it would be interesting to examine whether or not customers cooperate on organisations' environmental performance, in which circumstances it flourishes, and how customers could collaborate with organisations in order for them to improve their environmental performance.

Considering National Geographic (2016), it was decided to study organisations located in Brazil in order to understand the role of customers in cooperation on organisations' environmental performance. Beyond the findings of National Geographic, Brazil has an institutional environment that makes it an interesting focus of investigation. Brazil stands out in the context of Latin America for its political commitment to Ecological Modernisation (EM) (Jabbour \& Jabbour, 2014), which indicates the coexistence of economic and environmental development (York \& Rosa, 2003). In 2010, an important environmental institutional milestone towards green growth was launched, the National Policy on Solid Waste (NPSW). This law establishes extended 
responsibility for the management of residues from manufacturers, importers, distributers, retailers, end customers and those in charge of urban solid residue management in reverse logistics of post-consumption residues and packaging (Brasil, 2014).

Because of such a new institutional setting, organisations are likely to seek operational practices that are more appropriate environmentally. Since environmental responsibility will be required from various tiers of a productive chain, Green Supply Chain Management (GSCM) practices emerge as an opportunity to improve competitiveness and the environmental performance of organisations in the context of EM driven policy (Sarkis et al., 2011).

External GSCM practices - green purchasing and cooperation with customers - may catalyse the response of organisations to EM. Schoenherr et al. (2014) claim that green purchasing is related to a superior environmental performance and it can be considered as a strategic resource. On the other hand, there is a dearth of empirical studies investigating whether similar claims might be made about cooperation with customers, notwithstanding a potentially crucial role of customers to promote green concepts in supply chains (Kumar et al., 2014).

In order to address the research purpose, this article draws on GSCM literature but also on EM literature and Resource Dependence Theory (RDT). Considering that the external environment of the companies established in Brazil is embedded in an EM context, because of the NPSW, and that RDT tries to explain the behaviour of companies based on context interdependencies (Wolf, 2014) and that sustainability management is such a new resource dependence between focal firms and their supply chain partners (Schnittfeld \& Busch, 2015), then such traditional theories can enhance comprehension of the relationship that exists between the adoption of external GSCM practices and environmental performance. This theoretical framing responds to a gap pointed out by Sarkis et al. (2011), in terms of lack of research associating GSCM-EM to GSCM-RDT. To develop the research, a two stage methodology was used: a survey of ISO14001-certified companies in Brazil in order to verify whether external GSCM practices (green purchasing and cooperation with customers) influence environmental performance; and multiple-case studies with four large, ISO-certified Brazilian companies to obtain a deeper understanding of the roles of green suppliers and customers in a GSCM context.

The paper contributes to overcome gaps in current GSCM literature in the following aspects: it presents empirical results supporting the relationship between GSCM and environmental performance, thus contributing to filling the gap pointed out by Sarkis et al. (2011); it advances GSCM studies by extending the literature on RDT to discuss the relevance of cooperation with customers and green purchasing as significant resources for businesses, contributing to filling another gap pointed out by Sarkis et al. (2011); it focuses on cooperation with customers in the GSCM context, an aspect that has been little explored so far according to Junquera et al. (2012); it presents a matrix proposal for understanding the relationship between the roles of green suppliers and customers for achieving higher environmental performance in a GSCM context, thus addressing a knowledge gap on the role of customer integration in the extended responsibility-performance link, as highlighted by Lai et al. (2014).

\section{Theoretical Framework}

\subsection{GSCM and environmental performance: formulation of research hypotheses}

Considering that sustainable consumption habits are growing, environmental responsibility will be required not only from companies, but from various tiers of productive chains, consequently, GSCM practices emerge as an opportunity to improve competitiveness and the environmental performance of organisations. GSCM is a strategy that manages the flow of materials along the value chain through different stages such as acquisition, production and distribution with the purpose of protecting the environment by safeguarding natural resources and reducing global warming and carbon emissions (Ageron et al., 2012).

GSCM practices may be understood, according to Vachon and Klassen (2006), as a series of inter-organisational activities arising from two options to improve environmental management: mutual problem solving and risk minimization. GSCM practices may be classified as internal and external. Internal GSCM practices correspond to the activities that are performed without the direct involvement of suppliers and customers such as internal environmental management, ecodesign and investment 
recovery. External GSCM practices include activities that involve transactions with suppliers and customers such as green purchasing and cooperation with customers (Zhu et al., 2008).

As stated by Zhu et al. (2012) the scarcity of empirical findings supporting a clear relationship between the adoption of GSCM and the improvement of environmental performance has become a barrier for manufacturing organisations that try to justify the implementation of GSCM practices. Research results on this subject remain inconclusive in terms of the influence of external GSCM. The results are mixed, and although a majority of studies support that external GSCM practices affect environmental performance, other studies have failed to find a significant relationship or found a weak one (i.e., Zailani, et al 2012). In addition, most of the studies address the GSCM practices or external GSCM practices in an aggregate manner, in other words, they do not discuss the individual relationship between green purchasing (GP) and environmental performance and between cooperation with customers (CC) and environmental performance (Yang et al., 2013; Diabat et al., 2013; De Giovanni \& Vinzi, 2012; De Giovanni, 2012; Chien \& Shih, 2007; Zhu, Sarkis \& Geng, 2005; Zhu \& Sarkis, 2004).

Table 1 indicates the main studies that have addressed the relationship between each external GSCM practice and environmental performance in detail.

Table 1: The main studies that have assessed the specific relationship between external GSCM practices and EP.

\section{Study}

Chien \& Shih (2007)

Eltayeb et al. (2011)

Zailani et al. (2012)

Green Jr. et al. (2012a)

Diabat et al. (2013)

Youn et al. (2013)

Laosirihongthong et al. (2013)

Yang et al. (2013)

Gotschol et al. (2014)

Mitra \& Datta (2014)

\section{Relationship between External GSCM Practices and EP}

$$
\mathrm{GP}=+\mathrm{EP}
$$$$
\mathrm{GP}=* \mathrm{EP}
$$

$$
\mathrm{GP}=* \mathrm{EP}
$$

$\mathrm{GP}=* \mathrm{EP}$

$\mathrm{CC}=+\mathrm{EP}$

$\mathrm{CC}=+\mathrm{EP}$

$\mathrm{GP}=+\mathrm{EP}$

$\mathrm{GP}=+\mathrm{EP}$

$\mathrm{GP}=+\mathrm{EP}$

$\mathrm{CC}=+\mathrm{EP}$

$\mathrm{GP}=+\mathrm{EP}$

$\mathrm{GP}=+\mathrm{EP}$

\section{Justification Given by the Study}

Without comments from the authors. The authors suggest that it is possible that the respondents understood that the improvement in environmental performance is directly related to suppliers and indirectly related to the company.

The authors believe that it is possible that the respondents understood that the improvement

in environmental performance is directly related to suppliers and indirectly related to the company.

The relationship between GP and EP was not expected to be significant and the justification given is the profile of the sample studied - US businesses.

Customer cooperation involves activities that aim at improving environmental performance and the capability of the customers to participate in joint projects of product development and green innovation.

Environmental performance is assured when important suppliers successfully comply with the environmental hygiene standards that impress and attract customers.

Without comments from the authors.

According to the authors, with a greater level of external collaboration, partners and customers have jointly established common goals, shared planning and worked together to reduce pollution or other environmental impacts.

The authors believe that collaboration is a key component to improve environmental performance.

The authors state that, according to the Transaction Cost Economics, monitoring costs for suppliers at arm's length are greater than for suppliers in collaborative relationships. 
Note: + affect positively; * insignificant relationship.

Usually, according to Table 1, the authors that study the particulars of each external GSCM practice and their relationships to EP indicate that $\mathrm{CC}$ and GP have a tendency to positively affect the EP of an organisation. However, only one study shows that both GP and CC are significant (Yang et al., 2013). So, it is possible to affirm the first hypothesis of the research.

H1: the adoption of external GSCM practices positively influence the EP of organisations.

This hypothesis is broader than other hypotheses, due to the fact that it is used to confirm a general assumption of this research, which is, somehow, either cooperation with suppliers (through GP), or with customers, influences environmental performance.

The focus of most of the studies in Table 1 is the role and participation of suppliers in the GSCM process (e.g., Handfield et al., 2005; Darnall et al., 2008; Nawrocka, 2008; Hsu \& Hu, 2008; Nawrocka et al., 2009; Arimura et al., 2011; Tate et al., 2014; Bhattacharya et al, 2014). According to GSCM literature GP increases EP because it reduces transaction costs (Mitra \& Datta, 2014) and therefore facilitates access to new greener technologies. Thus, the second hypothesis of this research is:

H2a: GP will have a significant impact on EP.

The GSCM literature has seen customers as actors that exert regulatory pressure and somehow make an organisation seek changes in products and processes to meet the changes in consumption standards in order to improve the EP of the organisation (Handfield et al., 1997; Hall, 2001; Lai et al., 2012; Gualandris \& Kalchschmidt, 2014). Generally, research indicates that the way in which an organisation responds to customer pressures is based on activities related to green purchasing and therefore customers' influence will be captured by the extent of Green Purchasing (Walton et al., 1998; Walker \& Jones, 2012).

There are works which address the perspective of CC, but they do not explore the role of customers in cooperation. Govindan et al. (2013) concluded that in the context of companies in the Brazilian electrical and electronics industry, cooperation with customer practice in ecodesign is crucial to improve their environmental performance. Moreover, according to Chan et al. (2012), under a situation of high competition, if a small business is able to work in close collaboration with their customers to minimise the negative environmental impacts of their distribution logistics activities, it will enjoy an even greater level of performance. In a regulatory context where extended responsibility is proposed, Lai et al. (2014) believe that the success of extended responsibility practices need cooperation with customers for returning products, recycling and final disposal. Thus, extended responsibility may depend on how much customers consider it to be their responsibility to participate in product devolution programs. Junquera et al. (2012) have studied a sample of Spanish companies and verified that taking the customers' environmental demands into account, along with close environmental manufacturer-cooperation with customers have positively influenced green competitive advantage.

Therefore, the third hypothesis of this research is:

\section{H2b: CC will have a significant impact on EP.}

Figure 1 presents the hypotheses of the research. GP and CC are constructs that represent the external GSCM practices construct. 


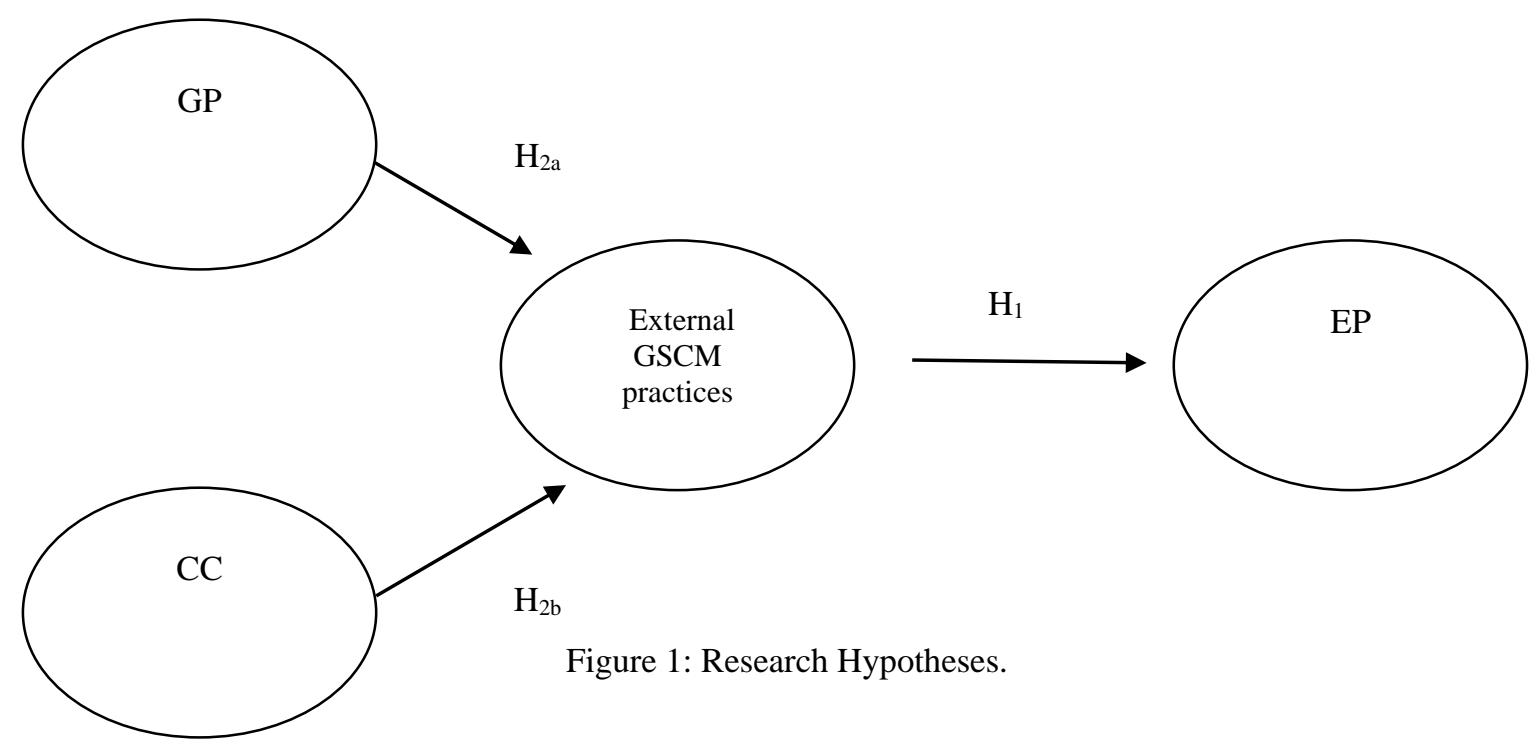

There is evidence that either cooperation with suppliers (through GP) or with customers, influences environmental performance. However, discussion on customers' roles in cooperation on organisations' environmental performance can be developed further, since customers need to be taken into account as a source of collaboration instead of as a source of pressure. Additionally, there is limited evidence regarding how customers could collaborate with organisations in order to improve their environmental performance and in what circumstances this happens. So, this article tests hypotheses in order to understand the assumptions of this research, because, if the sample does not present a positive effect between external GSCM practices and environmental performance, it will not be possible to discuss customers' role in the context of GSCM. Aspects related to how the hypotheses were tested are in section 3.

\subsection{Ecological Modernisation and Resource Dependence Theory}

The primary focus of EM is on institutional transformation which is committed to achieving an environmentally sustainable transformation of production and consumption (York \& Rosa, 2003). EM seeks to develop methods and models to reduce environmental impacts through measures such as reducing gas emissions and waste material, substituting resources and minimising resource consumption (Jay \& Morad, 2007).

Mol (2000) proposes two pillars of EM: (a) production and product technologies are transformed into broader systems that consider more than end-of-pipe technologies; and (b) government has an important role, jointly with other players, in the development of environmental policy, assuming the role of conductor of the market and cultural transformation. As stated by Janicke (2008), there are two forces that drive EM: (a) a good environmental regulation (smart regulation) that has clear rules, but flexible mechanisms, and (b) the increase of risks for businesses that operate under different environmental governance jurisdictions.

In accordance with Murphy and Gouldson (2000), regulation is central to green growth and EM. Regulations may help to solve environmental problems and, at the same time, encourage economic actors to become more competitive by forming coalitions and shifting resources from "brown" to "green" (Vazquez-Brust et al, 2014). GSCM practices are in line with EM and green growth because environmental policies may promote the adoption of GSCM and demonstrate that it pays off (Sarkis et al. 2011; Park et al., 2010).

The adoption of EM requires resources from companies (financial, human resources, knowledge, and time). EM emphasises collaboration as one possible pathway to acquire resources and, because of that, Resource Dependence Theory (RDT) is relevant to analyse corporate implications of EM. More concretely, RDT contributes to understanding the roles of suppliers and 
customers in improving the environmental performance of organisations through collaborative GSCM, since it tries to explain the behaviour of companies according to contextual interdependencies (Wolf, 2014). Interdependence exists whenever one actor does not entirely control all of the conditions necessary for the execution of an action or for obtaining the outcome desired from the action (Pfeffer \& Salancick, 1978).

An essential assumption in RDT is that organisations are seldom internally self-sufficient with respect to strategically important resources, leading them to depend on other organisations (Hillman et al., 2009). Because of that, organisations try to reduce uncertainties and manage such dependence by carefully structuring their associations with other organisations and market players to create symbiotic interdependencies between organisations (Ulrich \& Barney, 1984; Paulraj \& Chen, 2007).

Changes in the regulatory landscape created by EM are likely to trigger stronger levels of external GSCM. New legislation creates problems of uncertainty or unpredictability to organisations, which have not yet developed clear understanding of how they can respond effectively to regulation (outcome uncertainty). Organisations facing uncertainty attempt to cope with it by restructuring their exchange relationship, which means increasing the mutual control over each other's activities, or, in other words, increasing the behavioural interdependence of supply chain actors (Pfeffer \& Salancick, 1978).

In the context of the NPSW, Brazilian companies face increased uncertainty. They need to develop new ways to minimise waste arising from the use of their products; therefore they face uncertainty in terms of appropriate actions. They can attempt to address NPSW demands through technological innovation (weak EM, for instance biodegradable packaging) or through customers' behavioural change (strong EM, for instance recycling and reuse in households), or a combination of the two. Both technological innovation and behavioural change create uncertainties regarding supply of inputs and demand for outputs. RDT suggests that increased coordination and interdependence with suppliers and customers in the supply chain is more likely to lead to reduced uncertainty in outcomes of actions in response to NPSW. Thus, we can expect that successful companies will engage in cooperative relationships not only with suppliers but also with customers, as the latter are crucial to assure stability in throughput of new products.

Recollecting the research purpose to examine whether or not customers cooperate on organisations' environmental performance, in which circumstances CC would flourish, and how customers could collaborate with organisations in order to improve their environmental performance, Figure 2 illustrates the conceptual framework of the research. Based on an analytical cut-off of the perspective of a focal company concerning the adoption of external GSCM (GP and CC) practices and their impact on EP, such companies are analysed in an EM context, illustrated by NPSW; and the relationships and environment are analysed from an RDT point of view. Consequently, EM and RDT theories are useful in this research due to the fact that they support the comprehension of circumstances in which customers' roles could flourish in collaborating with companies for better EP. 


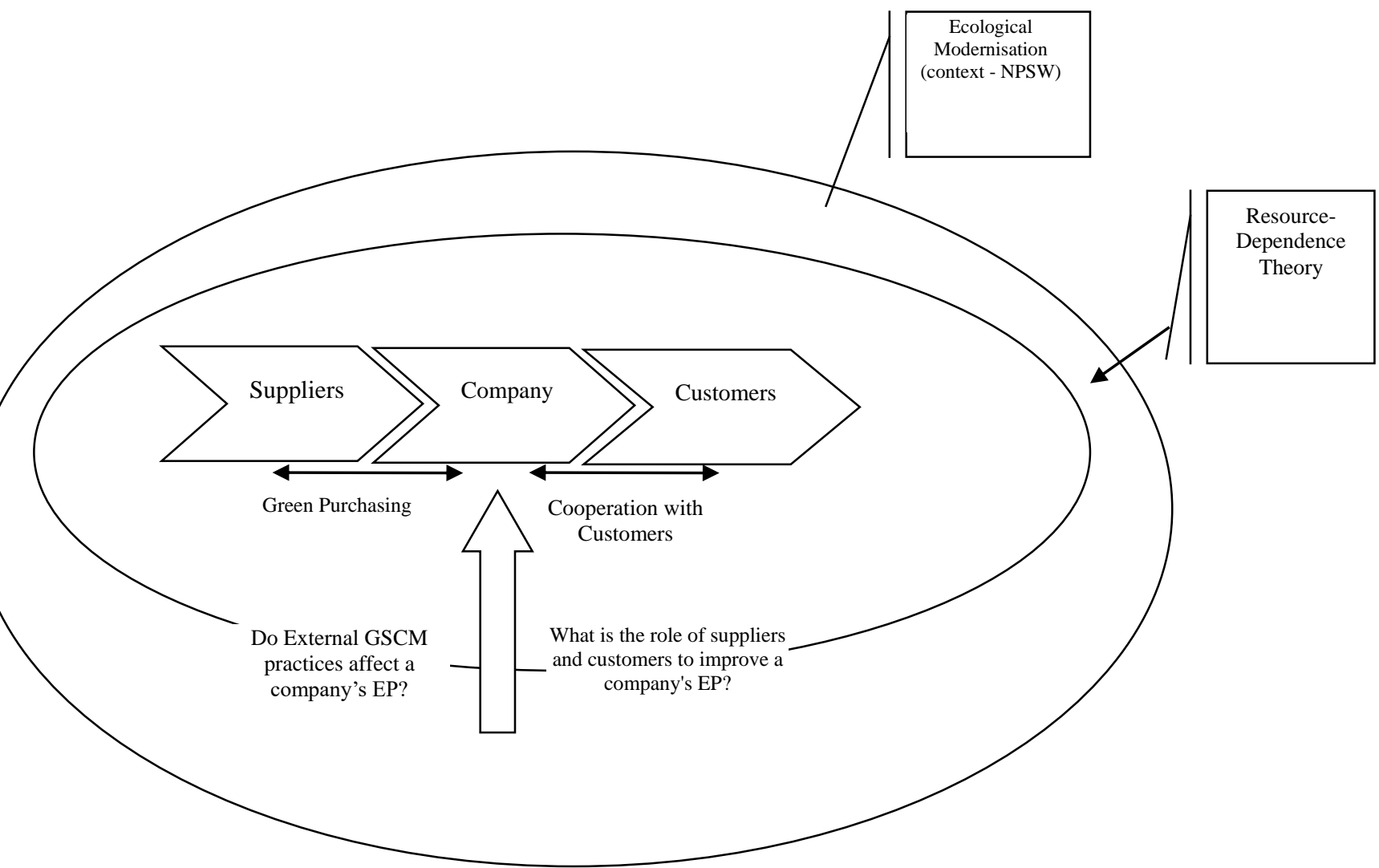

Figure 2: Conceptual framework of the research.

\section{Research procedures}

This research is based on a multi-method model, in other words it has both a quantitative and a qualitative stage. The quantitative stage is based on a survey and the qualitative stage is based on a multiple-case study.

There are arguments in favour of a quantitative-qualitative approach for methodological triangulation. Qualitative data is not extensively used to develop hypotheses, it is recommended for providing a better understanding of survey findings (Modell, 2005). Similarly, according to Sieber (1973), surveys should be conducted before case studies, especially to provide a broad perspective of the research field, and the evidence which emerges from a survey can be further explored in case studies. Additionally, results from surveys guide selection of the sample to conduct case studies (Jick, 1979).

The next sections describe each stage of the research in detail.

\subsection{Research focus}

The group of companies studied during the research, both through the survey and multiple-case studies, are: (a) companies certified by the INMETRO (National Institute of Metrology, Quality and Technology - an accrediting Brazilian agency) and by other agencies that award the ISO 14001 certification; and (b) four large companies located in the State of São Paulo and that are focal companies in their supply chains. The first sample of respondents was chosen because they were awarded ISO 14001 certification and consequently tended to have more GSCM actions (Nawrocka et al., 2009; De Sousa Jabbour et al., 2013); the second sample of respondents was chosen because large companies have an inclination to stand out in the adoption of environmental management and GSCM practices, once the size of companies matters (González-Benito \& González-Benito, 2006; Zhu, Sarkis, Lai \& Geng, 2008). Additionally, the group of companies represents a sub-sample for the survey, following Jick's (1979) guidelines. Other characteristics that were taken into consideration to choose the companies participating in the 
multiple-case study were: (1) they have environmentally friendly products that were developed by the companies themselves; and (2) national or international rankings recognize them as highly sustainable companies. A specific product was studied for each company to better understand the adoption of the external GSCM practices and their implications for EP.

The survey questionnaire was sent to the manager in charge of each company's environmental management, according to the information (name, e-mail and telephone for contact) disclosed in the INMETRO website. The multiple-case study script was applied to the managers of the environment, purchase and product development divisions. Assembly companies that are focal in their chains were chosen for the multiple-case because they tend to be the ones that encourage the adoption of GSCM practices (Gunasekaran et al., 2013), besides having more knowledge of the paths of the supply chain in which they are inserted.

Generally speaking, the profile of the survey respondents is: (1) $50 \%$ of the respondents stated they consider themselves to be at a proactive level of environmental management, (2) $42 \%$ of the respondents are medium-sized companies (100 to 499 employees) and 37\% are large-sized companies (more than 500 employees), (3) all companies belong to the manufacturing industry. Table 2 presents the characterisation of sample of the survey by manufacturing sector.

Table 2: Sample - characterisation of firms' profile by the most representative manufacturing activities.

\begin{tabular}{cc}
\hline Sector & Percentage \\
Chemical products & $24 \%$ \\
Electronics products & $11 \%$ \\
Auto parts & $20 \%$ \\
Transport vehicles & $11 \%$ \\
Equipment and machines & $4 \%$ \\
Food and drink & $4 \%$ \\
Others & $26 \%$ \\
\hline
\end{tabular}

\subsection{Research variables and data collection procedures}

\subsubsection{Survey}

\section{$\underline{\text { Survey variables }}$}

Table 3 presents the variables selected to conduct the survey and their respective measurement scales. Such variables were selected because they are largely used in other research that addresses GSCM practices.

Table 3: Survey Variables.

\begin{tabular}{|c|c|c|}
\hline Construct & Variables & $\begin{array}{l}\text { Scale adopted in the } \\
\text { research }\end{array}$ \\
\hline $\begin{array}{l}\text { Green Purchasing (GP) } \\
\text { Definition: Trying to reduce } \\
\text { sources of waste and promote } \\
\text { recycling of purchased } \\
\text { materials without adversely } \\
\text { affecting performance } \\
\text { requirements of such materials } \\
\text { (Min \& Galle, 2001) }\end{array}$ & $\begin{array}{l}\text { GP1 - Suppliers' ISO } 14001 \text { certification (Zhu \& } \\
\text { Sarkis, 2004) } \\
\text { GP2 - Cooperation with suppliers for } \\
\text { environmental objectives (Zhu \& Sarkis, 2004) } \\
\text { GP3 - Providing design specification to suppliers } \\
\text { that include environmental requirements for } \\
\text { purchased items (Zhu \& Sarkis, 2004) } \\
\text { GP4 - Second-tier supplier environmentally } \\
\text { friendly practice evaluation (Zhu \& Sarkis, 2004) } \\
\text { GP5 - Environmental audit for suppliers' internal } \\
\text { management (Zhu \& Sarkis, 2004) }\end{array}$ & $\begin{array}{l}\text { 5-point Likert scale } \\
\text { ranging between } 1 \\
\text { (minimum degree of } \\
\text { implementation) and } 5 \\
\text { (maximum degree of } \\
\text { implementation) }\end{array}$ \\
\hline $\begin{array}{l}\text { Cooperation with Customers } \\
\text { (CC) } \\
\text { Definition: Includes exchange } \\
\text { of technical information and } \\
\text { requires a mutual willingness } \\
\text { to learn about each other's } \\
\text { operations in order to plan and } \\
\text { set goals for environmental } \\
\text { improvement (Vachon \& } \\
\text { Klassen, 2008). }\end{array}$ & $\begin{array}{l}\text { CC1 - Cooperation with customers for cleaner } \\
\text { production (Zhu \& Sarkis, 2004) } \\
\text { CC2 - Cooperation with customers for green } \\
\text { packaging (Zhu \& Sarkis, 2004) } \\
\text { CC3 - Cooperation with customers for eco-design } \\
\text { (Zhu \& Sarkis, 2004) }\end{array}$ & \\
\hline
\end{tabular}




\begin{tabular}{llllll}
\hline Environmental & Performance & EP1 - The emission of pollution/waste (Sarkis \& & 5-point & $\begin{array}{r}\text { Likert } \\
\text { beale }\end{array}$ \\
(EP) & & Rasheed, 1995) & ranging & between & 1 \\
Definition: measurable results & EP2 - Compliance with environmental legislation & (maximum & \\
of an & organisation's & (Sarkis \& Rasheed, 1995) & deterioration) & and & 5 \\
management & of $\quad$ its & EP3 - Company's environmental reputation & (maximum & \\
environmental & aspects (ISO, & EP4 - Company's overall environmental & improvement). \\
2004) & & performance (Zhu et al., 2008) & & \\
\hline
\end{tabular}

Company size was added as control variable in accordance with existing literature stating that larger companies are more likely to achieve improved environmental performance (González-Benito \& González-Benito, 2006; Zhu et al, 2008, BurgosJimenez et al, 2012). This is in line with RDT predictions, since larger companies are more likely to have independent access to resources to improve performance (Mesquita \& Lazzarini, 2008).

\section{$\underline{\text { Survey data collection procedures }}$}

Before starting to collect the data, the content of the questionnaire was validated by five researchers from the environmental management field. Based on their recommendations, a few adjustments were made to some of the assertions and after that the instrument was pretested. The questionnaire was sent to five professionals from companies in the database. Those companies were not in the final sample. The researchers interacted with those five professionals via email to verify possible problems relating to the structure of the questionnaire. After that process, the questionnaire was ready.

The INMETRO database contained the register of 307 companies. In order to compose the initial sample, 23 other companies from the personal database of the research group were added, totalling 330 companies.

The survey questionnaire was hosted on a webpage and emails were sent to professionals in charge of the environmental management system of the companies registered in the database of the INMETRO, explaining the research and providing a link to access the questionnaire. A total of four batches of emails were sent between the second semester of 2012 and the first semester of 2013. Telephone calls were made to increase the number of responses, which resulted in 95 fully answered questionnaires.

Before ending the research, the appropriateness of the sample obtained was verified to see whether the 95 questionnaires indicated a statistically satisfactory level. To do so, the G*Power 3.1 software was used (Faul et al., 2007). The result indicated that the minimum number required was approximately 90 questionnaires.

The response rate was $28.79 \%$, which is considered very good taking into account the rates of responses cited in other recent research such as those conducted by Murillo-Luna et al. (2011) and Pereira-Moliner et al. (2012).

\subsubsection{Multiple-case study}

\section{Research script}

The script of the interviews was built so as to obtain arguments and examples of the relationship between external GSCM practices and improvements in the EP of organisations based on the perception of the professionals of the companies studied. Accordingly, to Siber's (1973) recommendation, case studies provide a better understanding of evidence emerging from a survey, consequently, the purpose of multiple case studies in this study is to understand how customers can collaborate with organisations in order to improve their environmental performance. Example of questions asked are:

- How does the company adopt the GP practice?

- How does the company adopt the CC practice?

- What is the role of suppliers in improving the environmental performance of the company?

- What is the role of customers in improving the environmental performance of the company? 
The research was performed during the first semester of 2014 and was conducted based on interviews (Table 43) with professionals that hold strategic positions in the sustainability, product development and purchase divisions. The interviews were recorded so the conversations that took place in the interviews could be reproduced. After the interviews, when access was allowed, notes were made regarding the company's production line and workplace environment to complement or generate the evidence than had been provided during the interviews. Secondary data was also provided by the interviewees or was obtained from public domain sources such as the company's website, the news, sustainability reports, and so forth. Analytical texts in each case were written based on the interviews, notes made during the interviews, perceptions of the direct remarks made and secondary data to obtain assertions and justifications about the relationship between external GSCM practices and EP were made.

Table 4: Information regarding the companies studied and the data collection process.

\begin{tabular}{|c|c|c|c|c|c|}
\hline \multirow{2}{*}{ 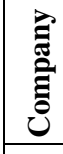 } & \multirow[b]{2}{*}{ Product } & \multirow[b]{2}{*}{ Description } & \multicolumn{3}{|c|}{ Data collection } \\
\hline & & & Interviews & $\begin{array}{c}\text { Documents, Websites and } \\
\text { lectures }\end{array}$ & $\begin{array}{c}\text { In loco } \\
\text { observations }\end{array}$ \\
\hline A & $\begin{array}{l}\text { Green polyethylene } \\
\text { biopolymer obtained } \\
\text { through ethanol } \\
\text { from sugar cane }\end{array}$ & $\begin{array}{l}\text { Company in the } \\
\text { chemical industry } \\
\text { leads the production } \\
\text { of thermoplastic } \\
\text { resins in the } \\
\text { Americas and is the } \\
\text { largest producer of } \\
\text { biopolymers in the } \\
\text { world }\end{array}$ & $\begin{array}{lc}\text { - Interview } & \text { with the } \\
\text { company's } & \text { Sustainability } \\
\text { Director } & \\
& \\
& \\
& \end{array}$ & $\begin{array}{l}\text { - Annual Sustainability Report } \\
\text { for } 2012 \text { and } 2013 \\
\text { - Videos of the event Design } \\
\text { for the Environment: } \\
\text { opportunities and challenges } \\
\text { for the Brazilian industry } \\
\text { - Health, Safety and } \\
\text { Environment Manual } \\
\text { - Integrated Management } \\
\text { System Manual } \\
\text { - Company's website }\end{array}$ & $\begin{array}{l}\text { - Visit made to } \\
\text { the company's } \\
\text { head offices }\end{array}$ \\
\hline B & $\begin{array}{|ll|}\text { Aircraft } & \\
\text { manufacturer with } \\
\text { environmental } \\
\text { requisites that are } \\
\text { intrinsic to the } \\
\text { product }\end{array}$ & \begin{tabular}{|l|} 
Government- \\
controlled semi- \\
public corporation. \\
One of the main \\
aeronautical \\
companies in the \\
world
\end{tabular} & $\begin{array}{l}\text { - Interview with two project } \\
\text { engineers for environmental } \\
\text { product development } \\
\text { - Interview with the person } \\
\text { in charge of the } \\
\text { Environment Division } \\
\text { - Interview with the person } \\
\text { in charge of sustainability in } \\
\text { industrial operations } \\
\text { - Interview with the leader } \\
\text { of the environmental project } \\
\text { team }\end{array}$ & $\begin{array}{l}\text { - Annual Sustainability Report } \\
\text { for } 2012 \\
\text { - Videos of the event Design } \\
\text { for the Environment: } \\
\text { opportunities and challenges } \\
\text { for Brazilian industry } \\
\text { - Company's website }\end{array}$ & $\begin{array}{l}\text { - Visit made to } \\
\text { the company to } \\
\text { perform the } \\
\text { research } \\
\text { - Technical visit } \\
\text { to the factory } \\
\text { floor }\end{array}$ \\
\hline C & $\begin{array}{l}\text { Cosmetic products } \\
\text { for daily use with } \\
\text { bio-natural } \\
\text { formulas, reduced } \\
\text { input and refill } \\
\text { packaging }\end{array}$ & $\begin{array}{l}\text { Leading domestic } \\
\text { company for non- } \\
\text { durable goods }\end{array}$ & $\begin{array}{l}\text { - Interview with the Supply } \\
\text { Division Coordinator } \\
-\quad \text { Answers to the } \\
\text { questionnaire sent by e-mail } \\
\text { by the Scientific, Ecodesign } \\
\text { and Environmental Impact } \\
\text { Manager }\end{array}$ & $\begin{array}{l}\text { - Annual Sustainability Report } \\
\text { for } 2012 \\
\text { - Videos of the event Design } \\
\text { for the Environment: } \\
\text { opportunities and challenges } \\
\text { for the Brazilian industry } \\
\text { - Slides of the social and } \\
\text { environmental training course } \\
\text { given to suppliers } \\
\text { - Company's website }\end{array}$ & $\begin{array}{l}\text { Visit made to } \\
\text { the company to } \\
\text { perform the } \\
\text { research } \\
\text { - Technical visit } \\
\text { to the factory } \\
\text { floor }\end{array}$ \\
\hline D & $\begin{array}{l}\text { Complete line of } \\
\text { household cleaning } \\
\text { products focused on } \\
\text { the 4Rs (Reduce, } \\
\text { Reuse, Recycle and } \\
\text { Respect } \\
\text { biodiversity) }\end{array}$ & $\begin{array}{l}\text { Leading company in } \\
\text { Brazil for household } \\
\text { cleaning solutions }\end{array}$ & \begin{tabular}{|l}
- \\
Interview with the \\
Product Research and \\
Development Manager \\
$-\quad$ Interview with the \\
Environment Coordinator \\
$-\quad$ Interview with the \\
Sustainability Manager
\end{tabular} & $\begin{array}{l}\text { - Slides on the environmental } \\
\text { performance of the complete } \\
\text { line of environmentally } \\
\text { improved products studied } \\
\text { - Company's website }\end{array}$ & $\begin{array}{l}\text { Visit made to } \\
\text { the company to } \\
\text { perform the } \\
\text { research } \\
\text { - Technical visit } \\
\text { to the factory } \\
\text { floor }\end{array}$ \\
\hline
\end{tabular}

\subsection{Data analysis procedures}

\subsubsection{Survey}

In order to test the research hypotheses (Figure 1), the Structural Equation Modelling (SEM) technique was used through the Partial Least Squares (PLS-SEM) of the SmartPLS 3 software (Ringle et al., 2015). According to Hair et al. (2011) such a 
technique is widely used in research in the marketing and management areas with the purpose of analysing the cause and effect relationships between latent constructs and it is a very effective technique to estimate causal relationships in theoretical models based on empirical data. Ringle et al. (2012) highlight that the main reasons for choosing the PLS-SEM are that it is useful for small samples, complex models, and hierarchical models and focuses on prediction and exploratory research (Richter et al., 2016). We use algorithms and bootstrapping on Consistent PLS (PLSc).

Each construct (GP, CC, External GSCM, EP) has variables that have values that need to be considered in the statistical analysis, so we applied the cut-off values during the data analysis as follows. For the evaluation of the outer model:

- For assessing convergent validity, the outer loadings or item reliability should be higher than 0.7 , but values higher than 0.5 are acceptable and Average Variance Extracted (AVE) should be higher than 0.5;

- For assessing discriminant validity, the square roots' AVE must be higher than the correlations among the constructs and heterotrait-monotrait ratio (HTMT) must be less than 0.90 .

- For assessing internal consistency reliability, we used composite reliability and rho_ $A$, which must be higher than 0.7 ;

- $\quad$ For assessing the stronger prediction/explanatory variance, we use the R-square. $\mathrm{R}^{2}$ small $=0.02 ; \mathrm{R} 2$ medium $=0.13$; R2 large $=0.26($ Cohen, 1992);

- For assessing potential bias of having only one key informant per firm, we use AFVIF to assess common method bias (Kock, 2015).

A reflective model was used to assess the conceptual model of the research. Numerous collinearities were detected between the variables of the GP and CC construct; thus, the two-stage/step approach was adopted. Such a technique can be used to assess the nature of the higher-order construct using a confirmatory tetrad analysis (Becker et al., 2012).

\subsubsection{Multiple-case study}

We used analytical procedures to create insights within each case and then compare across cases (Yin, 1984). First we developed thick descriptions for each case study, aggregating the variety of data described in Table 3 to capture the rich context (Langley, 1999). Two critical insights aligned with RDT sprang from the thick descriptions: i) Companies have different levels of access to different resources needed to address new regulatory requirements. Such levels of access influence the degree of interdependence on external actors and relevance of GP and CC; ii) customers and suppliers are assigned different roles according to different modes of response and levels of interdependence and their performance in such roles influences the EP performance of the company. So as to identify key themes deriving from these insights, a table (Table 9) was prepared coding the raw data (Miles \& Huberman, 1994). The following coding categories were used: "how does the company adopt the GP practice", "what is the role of the suppliers in improving the EP of the company", "how does the company adopt the CC practice" and "what is the role of the customer in improving the EP of the company". Such categories dictated the guidelines to systematise the data collected and are indicated in the columns in the Table 9. The rows in Table 9 contain the identification of the companies (A, B, C and D) and specific statements made by the interviewees or examples obtained from the interviews or secondary data to exemplify how the relationship between external GSCM practices and EP have been ascertained in the companies.

A cross-case analysis was performed to identify similarities and differences between the cases (Yin, 1984). The similarities have been highlighted in Table 9 with bold type. Based on Table 9, we were able to compare the results of the empirical research with the literature on the topic, proposing a relational matrix that theorises the roles of green suppliers and customers in a GSCM context (Gioia et al, 2013).

\section{Research results}


All the items considered in the conceptual model of the research presented good statistical quality levels, so none of the items had to be discarded. The metrics of the measurement model were obtained with the help of the SmartPLS 3 (Ringle et al., 2015). The key statistical indications presented satisfactory values that were above the minimum reference levels. The AVE values were above 0.62 for all of the latent variables and the composite reliability presented values above 0.82 (Table 5).

Table 5: Convergent validity and internal consistency reliability of results

\begin{tabular}{|c|c|c|c|c|c|}
\hline Latent Variables & Items/Indicators & Loadings & AVE & $\begin{array}{l}\text { Composite } \\
\text { Reliability }\end{array}$ & Rho_A \\
\hline \multirow[t]{5}{*}{ Green Purchasing } & GP1 & 0.78 & & & \\
\hline & GP2 & 0.88 & & & \\
\hline & GP3 & 0.86 & 0.62 & 0.89 & 0.90 \\
\hline & GP4 & 0.72 & & & \\
\hline & GP5 & 0.66 & & & \\
\hline \multirow[t]{3}{*}{ Cooperation with Customers } & $\mathrm{CC} 1$ & 0.83 & & & \\
\hline & $\mathrm{CC} 2$ & 0.89 & 0.75 & 0.90 & 0.86 \\
\hline & $\mathrm{CC} 3$ & 0.88 & & & \\
\hline \multirow[t]{2}{*}{ External GSCM Practices } & EGP1 & 0.84 & & & \\
\hline & EGP2 & 0.83 & 0.70 & 0.82 & 0.87 \\
\hline \multirow{4}{*}{ Environmental Performance } & EP1 & 0.83 & & & \\
\hline & $\mathrm{EP} 2$ & 0.82 & 0.73 & 0.91 & 0.88 \\
\hline & EP3 & 0.87 & & & \\
\hline & EP4 & 0.88 & & & \\
\hline
\end{tabular}

Note: all items in each variable have outer loading > 0.6; AVE > 0.5 and CR \& rho_A $>0.7$ rho_ $A$ has been recommended to assess the reliability of the PLS-SEM.

In addition to such indicators, the Fornell-Lacker Criterion validity and with heterotrait-monotrait ratio (HTMT) were verified. The Fornell-Lacker Criterion validity was obtained by comparing the square roots of AVE and the loads of the paths between the latent variables. The values of the square roots of AVE, shown on the diagonal in bold, demonstrate that they are acceptable (Table 6). Furthermore, we tested the discriminant validity for all latent variables in the model using heterotraitmonotrait ratio (HTMT). In Table 6, it can be seen that the value of HTMT was smaller than 0.90, which means that it meets the recommended rule of thumb (Henseler et al., 2015; Latan et al., 2016).

Table 6: Discriminant Validity with Fornell-Lacker criterion and HTMT

\begin{tabular}{lcccc}
\hline \multicolumn{1}{c}{ Latent Variables } & $\begin{array}{c}\text { Cooperation with } \\
\text { Customers }\end{array}$ & $\begin{array}{c}\text { Environmental } \\
\text { Performance }\end{array}$ & $\begin{array}{c}\text { External GSCM } \\
\text { Practices }\end{array}$ & $\begin{array}{c}\text { Green } \\
\text { Purchasing }\end{array}$ \\
\hline Cooperation with Customers & $\mathbf{0 . 8 7}$ & 0.44 & 0.56 & 0.64 \\
Environmental Performance & 0.39 & $\mathbf{0 . 8 5}$ & 0.51 & 0.46 \\
External GSCM Practices & 0.83 & 0.40 & $\mathbf{0 . 8 4}$ & 0.38 \\
Green Purchasing & 0.54 & 0.40 & 0.78 & $\mathbf{0 . 7 9}$ \\
\hline
\end{tabular}

Note: Square roots of average variances extracted (AVE's) shown on the diagonal must be higher than correlations. Below the diagonal elements are the correlations between the construct values. Above the diagonal elements are the HTMT values.

The tests indicated that all of the relationships analysed presented positive values as can be seen in Figure 3 and Table 7. The value of the variance inflation factor (VIF) generated for all the independent variables in the model is $<3.3$, which means that there was no collinearity problem between the predictor variables. The $\mathrm{Q}^{2}$ predictive relevance value generated excellent endogenous variables, i.e., $>0$, which means that the model has predictive relevance. The value of goodness of fit that is generated through the standardised root mean squared residual (SRMR) is equal to $0.11>0.095$, which means that our model fits the empirical data. Hair et al. (2017, p. 193), state that when using PLS-SEM, it is important to recognize that the term 'fit' has different meaning in the context of CB-SEM and PLS-SEM. Thus, the threshold is likely too low for PLS-SEM. This is because that the discrepancy between the observed correlations and the model-implied correlations plays a different role in CB-SEM and PLS-SEM (Solovida \& Latan, 2017). 


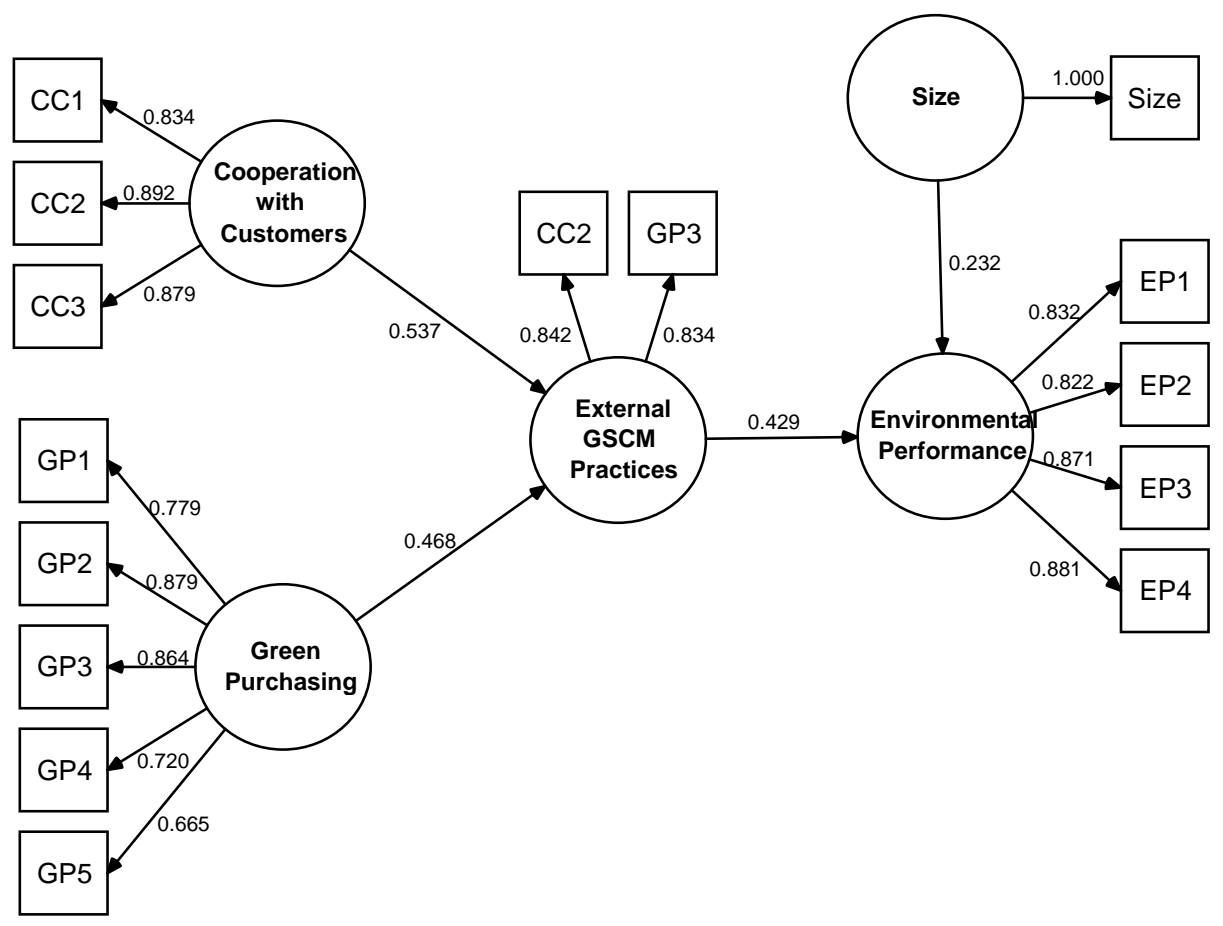

Figure 3: Results concerning the path diagram outer model with SmartPLS 3

Table 7: The results of the inner model analysis

\begin{tabular}{lccccccc}
\hline \multicolumn{1}{c}{ Latent Variables } & $\begin{array}{c}\text { R-Squared } \\
\left(\mathbf{R}^{2}\right)\end{array}$ & Adj. $\mathbf{R}^{2}$ & $\begin{array}{c}\text { Effect Size } \\
\left(\mathbf{f}^{2}\right)\end{array}$ & $\begin{array}{c}\mathbf{Q}^{2} \text { Predictive } \\
\text { Validity }\end{array}$ & VIF & AFVIF & SRMR \\
\hline Green Purchasing & - & - & 0.46 & - & 1.42 & & - \\
$\begin{array}{l}\text { Cooperation with } \\
\begin{array}{l}\text { Customers } \\
\text { External GSCM }\end{array}\end{array}$ & - & - & 0.34 & - & 1.42 & & - \\
Practices & 0.82 & 0.83 & 0.21 & - & 1.01 & & - \\
$\begin{array}{l}\text { Environmental } \\
\text { Performance }\end{array}$ & 0.21 & 0.20 & - & 0.20 & - & 1.37 & 0.11 \\
\hline
\end{tabular}

Note: The analysis showed that the AFVIF value obtained was $<3.3$, thus indicating no common method bias problem occurred.

Based on Figure 3, one may draw a few important conclusions: (1) The items with the largest loading on the constructs GP, CC and EP are, respectively, GP2 - Cooperation with suppliers for environmental objectives, GP3 - Providing design specifications to suppliers that include environmental requirements for purchased items, CC2 - Cooperation with customers for green packaging, EP3 - Company environmental reputation; and EP4 - Company overall environmental performance; (2) the relationship between external GSCM practices and EP is direct, positive and of large intensity $\left(\mathrm{R}^{2}=0.215\right)(\mathrm{Cohen}, 1992)$, which means that the environmental improvement of an organisation is moderately explained by the adoption of external GSCM practices; (3) both GP and CC have a positive relationship with external GSCM practices, where CC is a little more related than GP; (4) because of the high collinearities between the variables of the GP and CC constructs, the "repeated indicators" approach had to be aborted in the external GSCM practices construct, which resulted in the identification of the "GP3 - Providing design specification to suppliers that include environmental requirements for purchased item" and "CC2 - Cooperation with customers for green packaging" variables as the most statistically significant to represent the GP and CC construct in the external GSCM 
practices construct; (5) the size of the companies tends to control their EP, that is, the larger the company, the greater the possible EP.

In order to verify whether those positive relationships are, in fact, statistically significant, a bootstrapping of 2000 subsamples was applied. We tested the hypothesis with a view toward the coefficient parameter and the significant value generated from the $95 \%$ bias-corrected confidence intervals of each independent variable. T test values near $1.65,1.96$ and 2.58 will be considered with significance levels of $10 \%, 5 \%$ and 1\%, respectively (Hair et al., 2011, 2017). All of the values, besides being positive, are significant as shown in Figure 4 and Table 8.

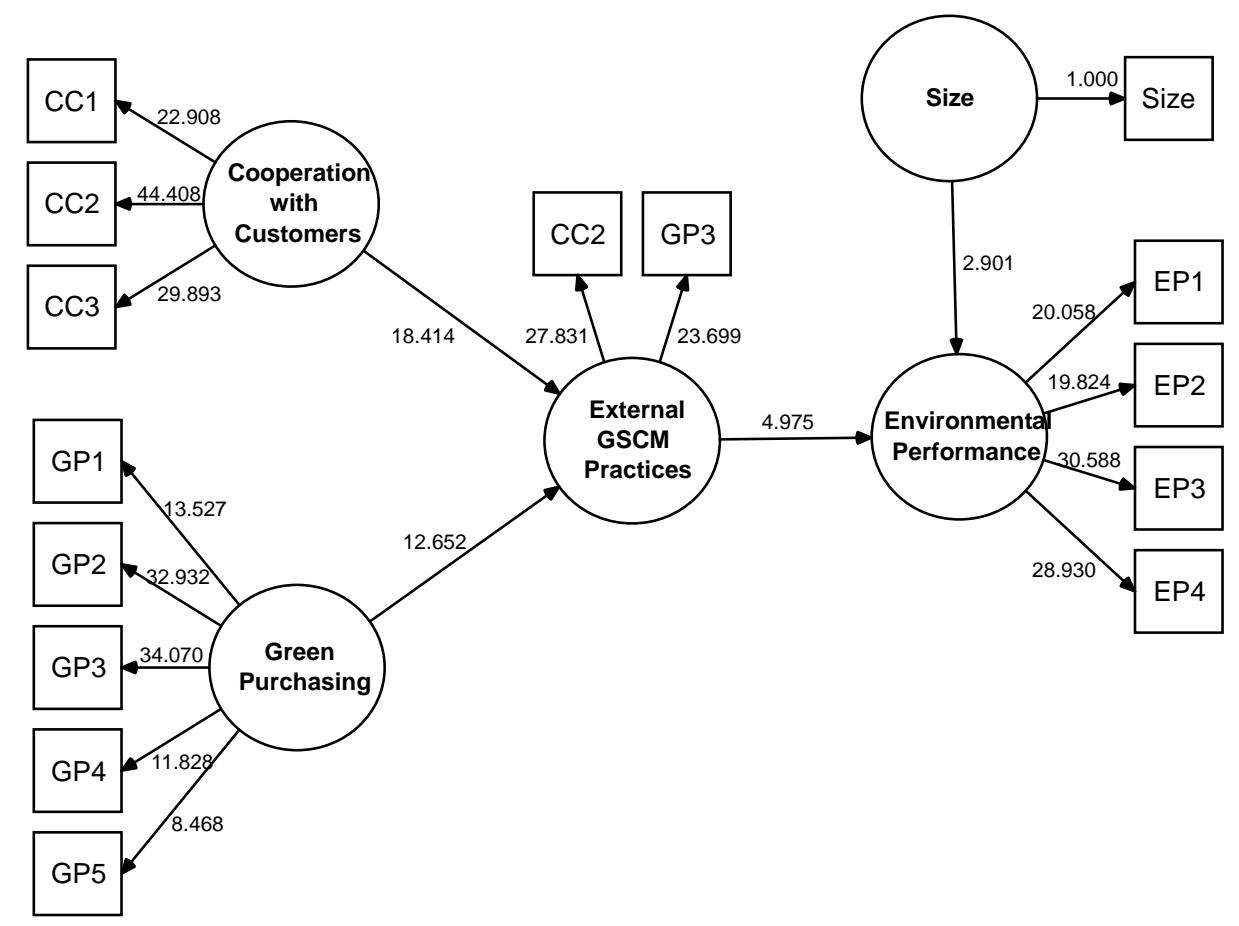

Figure 4: Results concerning the path diagram of the inner model with SmartPLS 3

Table 8: Hypotheses testing for relationship among variables

\begin{tabular}{|c|c|c|c|c|c|}
\hline $\begin{array}{c}\text { Structural path } \\
\text { Coef }(\beta)\end{array}$ & $\begin{array}{c}\text { Std. } \\
\text { deviation }\end{array}$ & P-Values & $\begin{array}{c}95 \% \text { BCa } \\
\text { CI } \\
\end{array}$ & Conclusion & \\
\hline $\begin{array}{c}0.030 .00 * *(0.003 \\
0.440) * * \mathrm{H} 2 \mathrm{~b} \text { supportedE- }\end{array}$ & 0.43 & 0.09 & $0.00 * *$ & $\begin{array}{l}(0.009,0.479)^{* *} \\
(0.000,0.686)^{* *}\end{array}$ & $\begin{array}{l}\text { H1 supported } \\
\text { H2a supported }\end{array}$ \\
\hline $\begin{array}{c}\mathrm{GSCM} \rightarrow \mathrm{EP} \\
\mathrm{GP} \rightarrow \mathrm{E}-\mathrm{GSCM}\end{array} \stackrel{\mathrm{EP}}{\rightarrow}$ & 0.47 & 0.04 & $0.00 * *$ & & \\
\hline $\begin{array}{l}\text { Size } \rightarrow \text { EP0.57 } \\
\mathrm{CC} \rightarrow \text { E-GSCM } \rightarrow \text { EP }\end{array}$ & 0.23 & 0.08 & $0.00 * *$ & $(0.006,0.228)^{* *}$ & \\
\hline
\end{tabular}

Note: **, * statistically significant at the 1 percent and 5 percent levels (one-tails), respectively.

Therefore, the research hypotheses were accepted, that is, both GP and CC practices are important to understand external GSCM practices and they positively affect the EP of an organisation. Moreover, we verified that the size of a company tends to influence its EP.

In the context of EM, regulatory changes have resulted in better environmental performance of those companies engaging more in GSCM as a way to pool resources to develop responses to regulation while increasing behavioural interdependencies with suppliers and customers to reduce outcome uncertainty.

Results from the survey were important to indicate that GP as well as CC can improve EP, but CC seems to be more influential than GP. Therefore, customers cooperate on organisations' environmental performance. The surrounding institutional 
environment across companies studied, Brazil's NPSW, could explain circumstances in which CC could flourish. This means it is an environment that requires extended responsibility from organisations. Therefore, a multiple-case study provides better understanding from evidence emerging from the survey, consequently, the purpose of the multiple-case study is to understand how customers can collaborate with organisations in order to improve their environmental performance.

\subsection{Multiple-case study results}

All four companies in the multiple-case study are large sized and Brazilian owned. They are all industry leaders in terms of environmentally improved products. Except for company C, which operates in the business to customer (B2C) format, all operate in the business to business (B2B) format. Except for company A, all companies deliver finished products to the customer. Company A supplies inputs for the production of packaging to its customers. All companies operate in a highly-competitive market structure, except for company B which operates in the context of a global oligopoly. All the case studies assessed their environmental performance through general ecoefficiency-based indicators such as, for example, water and power savings and waste reduction. However, it should be highlighted that companies A and C adopted broader and more advanced environmental performance indicators, mainly focusing on $\mathrm{CO}_{2}$ emissions and the Life Cycle Assessment approach.

Company A launched its environmentally improved product in 2010 and two important actions directed to suppliers and customers were instituted: (1) the ethanol suppliers are required to sign a document through which they agree to follow the Supplier Code of Conduct ${ }^{1}$; and (2) the creation of a green label to help identifying that the packaging produced from A's input is environmentally appropriate. According to the Sustainability Director, the role of suppliers in improving the EP of company A is as follows: "Suppliers may positively or negatively affect a company's environmental performance. The latter happens if they do not follow the technical specifications". Cooperation with Customers (CC) tends to take place when the company begins using the green label; by using returnable packaging_to avoid the excessive use of inputs and the generation of possible waste; and after implementing an institutional program directed to customers. The purpose of such a program is "to support the development of each customer based on shared know how" (secondary data) and, according to the Managing Director: "It addresses the customer competitiveness. It discusses a closer relationship between company A and its customers". According to the Sustainability Director, the role of the customer in improving the EP of company A is "to motivate the company to look for new products or solutions for current problems, such as looking for several forms of recycling plastic". This process is supported by a strong stakeholder engagement that includes not only customers but also R\&D institutes.

Company B began structuring design in the environmental area in 2011 to be able to start developing the first aircraft for the company with that concept. The aircraft will be launched in the next few years. Due to such an initial stage of developing an environmentally improved product, a few aspects of GP and CC have been adopted. As for the GP, the suppliers are required to have been awarded the ISO 14001 certification, or have an environment management system to qualify to be suppliers of the company. Suppliers have the responsibility to comply with the obligations stated in their agreements, such as the case of the REACH (Regulation on Registration, Evaluation, Authorization and Restriction of Chemicals), and the requirements of the aeronautical legislation. ${ }^{2}$ According to the Environment Project Team Leader, the role of the supplier to support the EP of company B is to "comply with the technical specifications and aeronautics legislation". "Currently, it is essential that suppliers satisfy the REACH requirements". With respect to the CC, the company has several customer niches: the executive, the defence and the commercial. The commercial European customer has indicated that it is possible that the environmental criterion will be

\section{1}

The code of conduct guides the GP practice at company A. Among the main guidelines of the code of conduct are: Avoid using the burning process for harvesting sugar cane; Protect biodiversity; Adopt good environmental practices; Respect human and labor rights; Support the analysis of the product life-cycle (secondary data)

$2 \quad$ Suppliers are audited by the company according to the National and International Supplier Qualification Program based on the following items: 1. Waste management, 2. Waste disposal, 3. Waste destination certificate, 4. Transport utilized, 5. Hazardous materials, 6. Effluents, 7. Licenses, 8. Legislation compliances and 9. Gas emissions. 
assessed in new agreements, but nothing has been put established so far. The same is the case of the American military customer. Presently, according to the interviewees "the customer influences, collaborates and interacts little with the company with regard to ecodesign and the company's environmental practices." Therefore, the role of the customer is not important in improving the EP of company B, for according to the Environment Project Team Leader, "customers do not demand anything explicitly concerning environmental performance requisites".

Company $\mathrm{C}$ has long been known for its reputation as being an environmentally appropriate company. Based on a Life Cycle Assessment (LCA) approach, the company has been trying to use bio-materials in its formulas and work with organic alcohol. In addition to being concerned with their packaging (using refills and recyclable materials), the plastic in the packaging of the products sold in refill format has a type II label, which indicates that the plastic is derived from renewable sources. Besides those aspects, the actions directed to GP that stand out are: The company informs its input suppliers of environmental prerequisites so that they qualify to become suppliers of the company; the company expects its suppliers will create procedures to manage water and energy consumption, waste generation and destination, and greenhouse gas emissions; in addition to measuring and reporting the performance in these aspects. There is a supplier's assessment program that audits them regarding the methodology employed to calculate the result of the performance in the indicators of the program $\left(\mathrm{CO}_{2}\right.$, water, and waste). According to the Supply Division Coordinator, the role of the supplier in supporting the EP of C is "to be innovating and proactive to achieve the environmental performance expected and assessed" and, in his opinion, because of the supplier's assessment program "suppliers look for changes in their processes [recycling] and try to improve their carbon footprints". With respect to the $\mathrm{CC}$ practice, the Ecodesign Manager says that "company $\mathrm{C}$ is always trying to understand consumer needs". There are more specific modalities for sustainability matters such as "the stakeholder engagement practice implemented several years ago to prepare the materiality matrix. Moreover, company $\mathrm{C}$ uses new digital media to connect to customers and users through new tools and open innovation initiatives". The Ecodesign Manager mentioned how the customers have contributed to improving the EP of company $\mathrm{C}$, “company $\mathrm{C}$ has developed refill options for most of its lines of products, proposing that consumers use the regular packaging with the purchase of refills with attractive prices. By motivating consumers to choose refills is a manner of reducing the company's medium environmental impacts [greenhouse gas emission indicator in $\mathrm{CO}_{2}$ equivalent]".

Company D differs from the other companies studied because when it launched a complete line of household cleaning products with ecodesign principles in 2010, it did not have a history of environmental management in its processes and organisational operations. Currently, to support the adoption of the GP practice of company D, suppliers provide information on the percentage of recyclable and renewable substances of the inputs supplied and are required to comply with environmental legislation. Usually, company D informs its suppliers of the technical specifications of its products, which include environmental aspects. The Product Research and Development Manager of company D said that the role of suppliers in improving the EP of company D is that "they have to present their own solutions, but only a few do that. The large multinational suppliers collaborate by offering workshops and benchmarking opportunities." The CC practice has not been very effective since "final consumers have not collaborated to produce environmentally appropriate products in the sense that they do not say they want an environmentally better product, maybe because there is already a line of products concerned with that". On the other hand, people that were interviewed said that large retail customers motivate the organisation to improve its EP through audits and proposals, even though they are not part of the assessment requisites of company D. Company D is beginning to work with its B2B retail customers to verify the way they store their products in order to avoid damaged packaging; therefore, the generation of solid waste. By trying to avoid damage, the company expects to reduce the consumption of inputs (Environmental Coordinator for company D).

Table 9 summarises the main results of the multiple-case study. The most significant evidence/arguments of each case that were used to identify the similarities and the differences of the cases are boldfaced.

Results from survey were important to indicate that GP as well as CC can improve EP, but CC seems to be more influential than GP. So, customers cooperate on organisations' environmental performance. The institutional environment 
surrounding the companies studied, Brazil's NPSW, could explain the circumstances in which CC could flourish. This means it is an environment that requires extended responsibility from companies. Therefore, the multiple-case study provides a better understanding of the evidence which emerged from the survey, and consequently, multiple-case studies show how customers can collaborate with companies in order to improve their environmental performance. 
Table 9: Summary of the main results of the multiple-case study.

\begin{tabular}{|c|c|c|c|c|}
\hline Company & How it adopts GP practice & $\begin{array}{l}\text { The role of suppliers in } \\
\text { improving the EP of the } \\
\text { company }\end{array}$ & How it adopts CC practice & $\begin{array}{l}\text { The role of customers in improving } \\
\text { the EP of the company }\end{array}$ \\
\hline A & $\begin{array}{l}\text { Ethanol suppliers follow the } \\
\text { guidelines of the Code of Conduct. } \\
\text { The company provides quality } \\
\text { technical specifications and the } \\
\text { Code of Conduct to their suppliers } \\
\text { t (interview). } \\
\text { Suppliers support the company } \\
\text { by providing information for the } \\
\text { LCA-Life Cycle Assessment } \\
\text { Approach (interview and } \\
\text { sustainability report). }\end{array}$ & $\begin{array}{l}\text { "Suppliers may positively or } \\
\text { negatively affect the } \\
\text { environmental performance of } \\
\text { the company if they do not } \\
\text { follow the technical } \\
\text { specifications" (interviewee). }\end{array}$ & $\begin{array}{l}\text { The company allows its customers to use the } \\
\text { green label for their packaging. This label } \\
\text { means that the plastic used in the packaging is } \\
\text { green polyethylene of renewable origin, that is, } \\
\text { from sugar cane ethanol. This is a way in } \\
\text { which customers seek advantages from green } \\
\text { marketing because they are using inputs with } \\
\text { renewable origins and that capture and store } \\
\text { CO2 (interview). } \\
\text { The company has a Technology and Innovation } \\
\text { Centre to perform tests and achieve solutions } \\
\text { related to products that meet the needs of } \\
\text { customers (sustainability report). The } \\
\text { company has an institutional program that } \\
\text { seeks solutions and shares knowledge with } \\
\text { customers (website and sustainability report). } \\
\text { The company also promotes the engagement of } \\
\text { other external stakeholders in this process, } \\
\text { such as Brazilian R\&D institutes. } \\
\text { The company makes reusable "big bags" } \\
\text { available to avoid the excessive use of } \\
\text { packaging (interview). }\end{array}$ & $\begin{array}{l}\text { Customers have an important role "to } \\
\text { motivate the company to look for } \\
\text { new products or solutions to current } \\
\text { problems such as looking for several } \\
\text { ways to recycle plastic, because of the } \\
\text { NPSW" (interviewee). }\end{array}$ \\
\hline B & $\begin{array}{l}\text { Suppliers need to provide evidence } \\
\text { that they have been awarded the } \\
\text { ISO } 14001 \text { certification or have an } \\
\text { environmental management } \\
\text { system to qualify to be suppliers of } \\
\text { the company (interview). } \\
\\
\text { The suppliers are audited by the } \\
\text { company according to the National } \\
\text { and International Supplier }\end{array}$ & $\begin{array}{l}\text { "Comply with the technical } \\
\text { specifications and aeronautic } \\
\text { legislation". Currently, it is } \\
\text { essential for suppliers to } \\
\text { comply with the REACH } \\
\text { (interviewee). }\end{array}$ & $\begin{array}{l}\text { "Presently, customers influence, collaborate } \\
\text { and interact little with the company with } \\
\text { respect to ecodesign and the company's } \\
\text { environmental practices" (interviewee). }\end{array}$ & $\begin{array}{l}\text { "Presently, customers do not demand } \\
\text { anything explicitly regarding the } \\
\text { company's environmental } \\
\text { performance requisites" } \\
\text { (interviewee). }\end{array}$ \\
\hline
\end{tabular}




\begin{tabular}{|c|c|c|c|c|}
\hline & Qualification Program (interview). & & & \\
\hline $\mathrm{C}$ & $\begin{array}{l}\text { Generally speaking, raw-material } \\
\text { suppliers are expected to create } \\
\text { procedures to manage water and } \\
\text { energy consumption and the } \\
\text { destination of waste and } \\
\text { greenhouse gas emissions. They } \\
\text { need to measure and report the } \\
\text { performance in those aspects } \\
\text { (website - secondary data). } \\
\text { According to the supplier } \\
\text { assessment program, suppliers are } \\
\text { audited with respect to the } \\
\text { methodology employed to calculate } \\
\text { the performance of the program } \\
\text { (CO2, water, waste) (interview). } \\
\text { The ecodesign team informs } \\
\text { suppliers about, and sends them, } \\
\text { product specifications that } \\
\text { include environmental requisites } \\
\text { (interview). Adopts a LCA - Life } \\
\text { Cycle Assessment Approach }\end{array}$ & $\begin{array}{l}\text { "Being innovative and } \\
\text { proactive to reach the } \\
\text { environmental performance } \\
\text { expected and assessed" } \\
\text { (interviewee). } \\
\text { "The supplier assessment } \\
\text { program makes them look for } \\
\text { changes in processes (recycling) } \\
\text { and seek improvements with } \\
\text { respect to carbon footprints" } \\
\text { (interviewee). }\end{array}$ & $\begin{array}{l}\text { "The stakeholder engagement has been } \\
\text { adopted for several years to prepare the } \\
\text { materiality matrix and capture the needs of } \\
\text { customers. Additionally, the company tries to } \\
\text { connect to customers and users through new } \\
\text { digital media and new tools and open } \\
\text { innovation initiatives" (interviewee). }\end{array}$ & $\begin{array}{l}\text { "The company has developed refill } \\
\text { options for most of its product lines, } \\
\text { proposing consumers reuse the } \\
\text { regular packaging by purchasing } \\
\text { refills with attractive prices. } \\
\text { Motivating consumers to choose refills } \\
\text { is a way of reducing the average } \\
\text { environmental impacts of the company. } \\
\text { The company's environmental } \\
\text { performance indicators - referring to } \\
\text { the impact per item sold, particularly } \\
\text { the greenhouse gas emission indicator } \\
\text { in CO2 equivalent - has shown that } \\
\text { this action is effective" (interviewee). }\end{array}$ \\
\hline $\mathrm{D}$ & $\begin{array}{l}\text { With the experience of } \\
\text { environmentally appropriate } \\
\text { products, suppliers have started to } \\
\text { collaborate more with the company, } \\
\text { for instance, by providing } \\
\text { information of the percentage of } \\
\text { recyclable and renewable } \\
\text { substances in the input provided } \\
\text { (interview). } \\
\text { Usually, the company provides the } \\
\text { technical specifications for its } \\
\text { products, which include } \\
\text { environmental issues (interview). }\end{array}$ & $\begin{array}{l}\text { "There are very proactive } \\
\text { suppliers (for example, the juice } \\
\text { manufacturer that sells orange } \\
\text { and lime peel to produce the } \\
\text { oils of the formulas of } \\
\text { environmentally appropriate } \\
\text { line of detergent), but the } \\
\text { objective is commercial. They } \\
\text { have the role of presenting } \\
\text { their own solution, but few do } \\
\text { that" (interviewee). }\end{array}$ & $\begin{array}{l}\text { "Final consumers have not collaborated to } \\
\text { produce environmentally appropriate } \\
\text { products in the sense that they do not say they } \\
\text { wish for an environmentally better product, } \\
\text { maybe because there is already a line of } \\
\text { products concerned with that" (interviewee). }\end{array}$ & $\begin{array}{l}\text { Large retail customers motivate the } \\
\text { organisation to improve } \\
\text { environmental management } \\
\text { practices through audits } \\
\text { (interviewee). } \\
\text { The company is beginning to work } \\
\text { with its retail customers to verify the } \\
\text { way they store their products in order } \\
\text { to avoid damaged packaging; } \\
\text { therefore, the generation of solid } \\
\text { waste and effluents. By trying to avoid } \\
\text { damage, the company expects to } \\
\text { reduce the consumption of inputs } \\
\text { (interviewee). }\end{array}$ \\
\hline
\end{tabular}




\section{Discussions: mixing survey and multiple-case studies to build a relational matrix}

Based on the survey, the research hypotheses were confirmed, in other words, GP and CC are important external GSCM practices and they positively and moderately affect EP. Another interesting result from the survey is that "providing design specifications to suppliers that include environmental requirements for purchased items" (GP3) and "cooperation with customers for green packaging" (CC2) are the variables that have greater significance to improve the EP of the organisations studied.

Considering the context of Brazil, with EM elements due to the NPSW, we may affirm that: (a) external GSCM practices are important for organisations' response to EM (Sarkis et al., 2011); and (b) customers, in particular, are likely to have a significant role because the NPSW, which proposes, among other things, extended responsibility with products after consumption, especially with packaging (Brasil, 2014). The greater significance of variable CC2 confirms the previous results of Lai et al. (2014), that the success of extended responsibility depends on customers. Another result from the survey is that the size of an organisation tends to affect EP, confirming the findings of González-Benito and González-Benito (2006) and Zhu, Sarkis, Lai, Geng (2008).

The multiple-case study helped us to understand more thoroughly how the managers of the organisations studied ascertained the positive relationship of GP and CC in improving the EP of their organisations. The variables "providing design specification to suppliers that include environmental requirements for purchased item" (GP3) and "cooperation with customers for green packaging" (CC2) of the survey were also noteworthy in the case studies.

In all cases, the companies acknowledged some level of symbiotic interdependence with external supply chain actors. Companies A (code of conduct and technical quality specifications), B (information contained in the agreement), $\mathrm{C}$ and $\mathrm{D}$ (the ecodesign team informs suppliers and sends product specification that includes environmental requisites to them) state they provide information and technical specifications of products with environmental criteria and depend on their suppliers' performance to satisfy environmental regulation. Further, companies A ("big bag" reusable, and green plastic to produce packaging with lower environmental impact), $\mathrm{C}$ (use of packaging that allows the use of refills) and D (actions that provide guidance to retailers referring to the correct storage of products to avoid packaging damage and waste) also presented clear actions that confirm the importance of cooperation with customers in green packaging to satisfy extended producer responsibility. So, both the survey stage and the multiple-case study have their own role in this research and they complement each other in providing a better understanding of cooperation with customers in the context of GSCM. The multiple-case study confirmed the results of the survey, and the importance of variables GP3 and CC2. The survey results provide a big picture and the multiple-case study provides a better understanding in detail.

Considering the way in which organisations adopt the GP and CC practices one may infer that:

- the roles of suppliers in improving the environmental performance of the organisations studied are either that of implementers or developers or both. Implementers passively comply with technical and contractual environmental specifications (companies A and B). Developers are proactive and innovative, providing solutions to the focal company or improving their processes beyond specifications (companies $\mathrm{C}$ and $\mathrm{D}$ );

- the role of customers tends to be either that of motivators, propagators or a combination of the two. Examples of customers as motivators of environmental improvement in the organisations include: 
communicating a product need and supporting the search for new plastic recycling solutions (company A), getting involved in stakeholder engagement (company C) and awakening the interest of the company in improving environmental management through audits (company D).

Our findings are aligned with Gualandris and Kalchschmidt (2014), who found that customers are an essential driver in motivating firms to begin and sustain the GSCM. Examples of customers as propagators of the environmental solutions of a company include the dissemination of the use of refill packaging to avoid excessive packaging consumption and disposal (company C), implementation of new stock management procedures to prevent package damage (company D) and the use of the focal company's green label on the product packaging to motivate the consumption of an environmentally appropriate product (company A). Therefore, pro-actively engaging customers with environmental practices helps to improve EP, which confirms the findings from Junquera et al. (2012) and of Kumar et al. (2014), who said that customers disseminate green concepts in supply chains.

Both suppliers and customers are important in the quest to improve EP, particularly in the current context of EM in Brazil, which agrees with the RDT, for according to Ramanathan and Gunasekaran (2014) one of the basic assumptions of RDT is that supply chains cannot be responsive to external demand without cooperation and support from other supply chain partners.

The contribution of this study is in emphasising not only the role of suppliers in the adoption of external GSCM practices, which has already been done by the existing literature (e.g., Handfield et al., 2005; Darnall et al., 2008; Nawrocka, 2008; Hsu \& Hu, 2008; Nawrocka et al., 2009; Arimura et al., 2011; Tate et al., 2014; Bhattacharya et al, 2014), but, mainly, the role of customers in the pursuit of improvements in the EP of organisations by means of external GSCM practices.

In this research, particularly, customers become important to support innovations in processes by means of instructions in audits and joint efforts to avoid packaging damage (company D), or in products (supporting solutions for different forms of recycling green plastics (company A)) and by means of changes in consumption habits - namely acceptance of the use of refills (company C) so that packaging does not become a problem for the organisations studied.

Existing literature focuses on customers as an actor that exert regulatory pressure and that somehow make the organisation look for changes in products and processes to satisfy the changes in consumption standards with the purpose of improving the EP of organisations (Handfield et al., 1997; Hall, 2001; Lai et al., 2012; Gualandris \& Kalchschmidt, 2014). Generally speaking, research findings indicate that an organisation responds to pressure from consumers when they begin green purchasing activities (Walton et al., 1998; Walker \& Jones, 2012). Nevertheless, customers in the first tier may have the role of cooperating with an organisation to answer to final consumer and stakeholder pressure. Further, this research contributes by shedding light on such a perspective of customer cooperation to complement GP actions, especially in the context of seeking to achieve EM.

The studied organisations depend on customers to: accept the use of refill packaging (company C); accept support to avoid product damage and consequent waste and the generation of residue for the company (company D); and use green plastics, green labels and to collaborate with the company to look for recycling solutions (company A). Therefore, RDT helps to understand such a dependence context of the organisations concerning customers that arises because of NPSW and EM. 
The case of company $\mathrm{B}$, in particular, did not significantly identify cooperation with customers, but because of market prospecting, B has already been moving ahead, designing products taking into account the environmental concept, once environmental criteria might be included in the bidding processes. A possible justification for such low cooperation with the customer is that the economic context of B is that of an oligopoly and as stated by Chan et al. (2012), a company may work in close collaboration with their customers to minimise negative environmental impacts if it operates under a situation of high competition. In such a situation as B therefore, the economic context tends not to favour actions of $\mathrm{CC}$ practices.

Considering the discussions presented herein and considering that three cases were operating in a context of B2B (companies A, B and D) and one case was in a B2C context (company C), it is possible to suggest differences between B2B and B2C in terms of changes in patterns of dependence as a result of EM. In a B2B context, the focal company, its suppliers and its customers all need to satisfy extended produced responsibility.

In a B2B context, extended producer responsibility has created mutual interdependencies. The customers of company A can benefit from its green marketing support; Company D's customers can benefit from cost reductions and image enhancement achieved through managing storage training provided by D. According to Hoejmose et al. (2012), for firms in the B2B context, having a proactive environmental strategy can produce considerable competitive advantages. On the other hand, in a context of B2C, the benefits offered to customers must include economic rewards to compensate asymmetries created by EM (extended responsibility). The focal company is highly dependent on their customers' acceptance of their role as propagators of company's environmental innovation in the market through the clients' adoption (for example, when company $\mathrm{C}$ promoted refill use). Therefore, company $\mathrm{C}$ needs to motivate customers to buy refills, offering them at very attractive prices.

Company B's situation is again atypical. Company B's corporate customers are not producers but providers of services, thus unaffected by extended producer responsibility regulation. However, the governmentcontrolled nature of the company gives B more discretion regarding the pace of innovation and buffers it from uncertainty and unpredictability in access to resources, thus making it relatively less dependent on customers.

Aiming to systematize this study's results (survey and multiple-case study), it is possible to propose an original relational matrix with possible roles of suppliers and customers for achieving a better EP in a GSCM context (Figure 5).

According to the proposed matrix, cooperation between the focal companies and their suppliers and customers might occur on two different levels: low and high. The level of cooperation depends on the centrality of environmental innovation as a resource to the company. We define centrality as degree of dependence of the environmental performance and business model of the company on supply of inputs based on environmental innovation and/or customers' demand for outcomes of environmental innovation. High centrality implies strong dependence on a stable supply of inputs and demand for environmentally friendly products. Low centrality indicates that fluctuations in supply/demand of environmental innovation do not have a significant impact on the core activities of the company

Low cooperation implies a neutral role of suppliers and customers during GSCM adoption. In this neutral context, environmental performance is considered in terms of operational ecoefficiency; i.e., environmental performance assessment as usual. On the other hand, the most advanced level of cooperation can be achieved, 
which involves intense cooperation between suppliers and customers. In this greener context, there is a focus on more advanced EP assessment, including $\mathrm{CO}_{2}$ emissions and the LCA approach.

As an illustration, it is possible to classify the studied companies from the neutral level to the intensive one, respectively Companies B, D, A and C. 


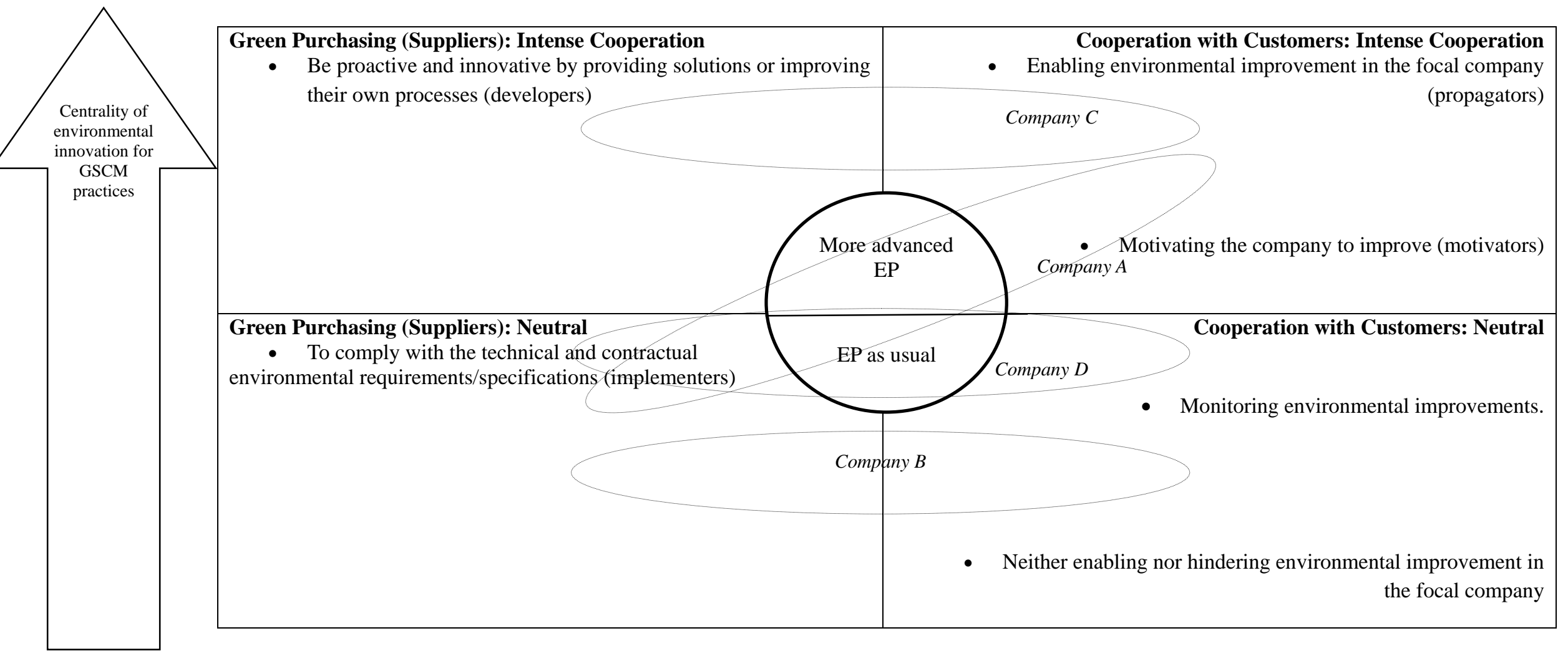

Figure 5 - Proposed relational matrix for understanding roles of suppliers and customers for achieving a better EP in a GSCM context. 
In short, this research provides an extension to the existing literature because it provides evidence of the relationship between GSCM, EP and RDT, where there are still research gaps (Sarkis et al., 2011). It has been found that, in the RDT context, $\mathrm{CC}$ weighs more than GP, where GSCM-CC is a more explicit dependence; and this work proposes an original and relational matrix of the possible roles of suppliers and customers in order to improve EP in the GSCM context.

\section{Conclusions}

This article investigated whether or not customers cooperate on organisations' environmental performance and in what circumstances this happens; and how customers can collaborate with organisations in order to improve their environmental performance. This research used both Ecological Modernisation Resource Dependence Theory to analyse the effects of external Green Supply Chain Management (GSCM) practices, namely, “Cooperation with Customers" (CC) and "Green Purchasing” (GP) on the Environmental Performance (EP) of organisations. A multi-method model of research was used, combining a survey and multiple-case studies of Brazilian organisations. The main results of the research are: customers can be seen as partners instead of villains in order to improve environmental management of companies; circumstances of extended responsibility, B2B, and environmental regulation according to Ecological Modernisation can require cooperation with customers; and the role of customers tends to be either that of motivators, propagators or a combination of the two. The level of cooperation depends on the centrality of environmental innovation as a resource to the company, following the perspective of Resource Dependence Theory.

It was identified that suppliers and customers are both very important; each one has a role in supporting organisations to improve their EP. However, because of extended responsibility, the cooperation with customers is important, especially regarding packaging and post-consumption, since organisations depend on customers for their products not to be the target of Brazilian environmental law. Such dependence of companies on customers creates an asymmetric symbiotic relationship where customers' acceptance of new products is crucial. Therefore, companies attempt to increase cooperation and dependence of customers in their products by offering customers (either corporate or citizens) benefits, adding value to the purchase.

In general, the focus of the studies has been the role of suppliers to GSCM, and this study sheds lights on the role of the customer considering RDT for GSCM in the context of EM, which represents the theoretical contribution of this research, which combines external GSCM practices, EP, EM and RDT in a single research. Additionally, unveiling in which circumstances customers are more likely to be willing to contribute to EP of focal companies is another contribution of this article. Extended responsibility aligned to EM principles tends to trigger cooperation with customers. Furthermore, this research indicates that B2B and B2C contexts require different strategies from organisations in order to encourage customers to contribute to EP of focal companies. The practical contribution of this research is the matrix proposed, which can guide organisations to develop strategies for encouraging suppliers and customers to participate in their initiatives of environmental innovation. Additionally, the matrix can provide recommendations to organisations in terms of the development of relationships with suppliers and customers for improving GSCM practices.

The practical implications from the research are that organisations that operate in Brazil or intend to do business with companies in Brazil need to consider the customer as a stakeholder that may play a different role to that of a pressure tier. Customers may induce and propagate environmental solutions, so creating communication and know-how exchange mechanisms is significant for the environmental improvement of organisations.

It may be useful in future research to disaggregate and explore in more detail, at the macro, meso and micro level, conditions that improve cooperation with customers in an EM context. For instance, inter-industry differences, impact of human resource practices and organisational forms, and influence of manager's environmental beliefs and attitudes could be looked at. The discussion of B2B and B2C contexts also needs further study, especially looking at the role of intermediaries (retailers, doorto-door, salespersons) through the lens of RDT. Customers should be investigated through deep case studies in order to understand 
their perspective, possibilities and difficulties in cooperating on the environmental performance of organisations. Further, the proposed relational matrix can also be tested.

The size of the sample of the survey, and the lack of other control variables (such as the industry, age of companies, B2B or B2C context etc.) in order to test moderation are the main limitations of this research. Another limitation is that this article focuses only on external GSCM practices, and the research could have had a beneficial result if it had conducted case studies with customer companies in addition to the inputs collected from focal companies.

\section{References}

Ageron, B., Gunasekaran, A., \& Spalanzani, A. (2012). Sustainable supply management: An empirical study. International Journal of Production Economics, 140(1), 168-182.

Arimura, T. H., Darnall, N., \& Katayama, H. (2011). Is ISO 14001 a gateway to more advanced voluntary action? The case of green supply chain management. Journal of Environmental Economics and Management, 61(2), $170-182$.

Becker, J. M., Klein, K., \& Wetzels, M. (2012). Hierarchical latent variable models in PLS-SEM: guidelines for using reflectiveformative type models. Long Range Planning, 45(5), 359-394.

Bhattacharya, A., Mohapatra, P., Kumar, V., Dey, P. K., Brady, M., Tiwari, M. K., \& Nudurupati, S. S. (2014). Green supply chain performance measurement using fuzzy ANP-based balanced scorecard: a collaborative decision-making approach. Production Planning \& Control, 25(8), 698-714.

Brasil. Ministry of Environment. Accessed in http://www.mma.gov.br/cidades-sustentaveis/residuos-solidos/politica-nacional-deresiduos-solidos

Chan, R. Y., He, H., Chan, H. K., \& Wang, W. Y. (2012). Environmental orientation and corporate performance: The mediation mechanism of green supply chain management and moderating effect of competitive intensity. Industrial Marketing Management, 41(4), 621-630.

Chien, M. K., \& Shih, L. H. (2007). An empirical study of the implementation of green supply chain management practices in the electrical and electronic industry and their relation to organizational performances. International Journal Environmental Science \& Technology, 4 (3): 383-394.

Cohen, J. (1992). A power primer. Psychological Bulletin, 122 (1), 155-159.

Coskun, S., Ozgur, L., Polat, O., \& Gungor, A. (2016). A model proposal for green supply chain network design based on consumer segmentation. Journal of Cleaner Production, 110, 149-157.

Darnall, N., Jolley, G. J., \& Handfield, R. (2008). Environmental management systems and green supply chain management: complements for sustainability?. Business Strategy and the Environment, 17(1), 30-45.

De Giovanni, P. (2012). Do internal and external environmental management contribute to the triple bottom line?. International Journal of Operations \& Production Management, 32(3), 265-290.

De Giovanni, P., \& Esposito Vinzi, V. (2012). Covariance versus component-based estimations of performance in green supply chain management. International Journal of Production Economics, 135(2), 907-916.

de Sousa Jabbour, A. B. L., Jabbour, C. J. C., Govindan, K., Kannan, D., Salgado, M. H., \& Zanon, C. J. (2013). Factors affecting the adoption of green supply chain management practices in Brazil: empirical evidence. International Journal of Environmental Studies, 70(2), 302-315.

Diabat, A., Khodaverdi, R., \& Olfat, L. (2013). An exploration of green supply chain practices and performances in an automotive industry. The International Journal of Advanced Manufacturing Technology, 68(1-4), 949-961.

Eltayeb, T. K., Zailani, S., \& Ramayah, T. (2011). Green supply chain initiatives among certified companies in Malaysia and environmental sustainability: Investigating the outcomes. Resources, Conservation and Recycling, 55(5), $495-506$.

Faul, F., Erdfelder, E., Lang, A. G., \& Buchner, A. (2007). G* Power 3: A flexible statistical power analysis program for the social, behavioral, and biomedical sciences. Behavior Research Methods, 39(2), 175-191.

Gioia,D.A., Corley, K, C, \& Hamilton, A. (2013) Seeking qualitative rigor in inductive research. Organizational Research Methods, 16, 15-31.

González-Benito, J., \& González-Benito, Ó. (2006). A review of determinant factors of environmental proactivity. Business Strategy and the Environment, 15(2), 87-102.

Gotschol, A., De Giovanni, P., \& Vinzi, V. E. (2014). Is environmental management an economically sustainable business?. Journal of Environmental Management, 144, 73-82. 
Govindan, K., Kannan, D., Mathiyazhagan, K., Jabbour, A. B. L. D. S., \& Jabbour, C. J. C. (2013). Analysing green supply chain management practices in Brazil's electrical/electronics industry using interpretive structural modelling. International Journal of Environmental Studies, 70(4), 477-493.

Green Jr, K. W., Zelbst, P. J., Meacham, J., \& Bhadauria, V. S. (2012). Green supply chain management practices: impact on performance. Supply Chain Management: An International Journal, 17(3), 290-305.

Gualandris, J., \& Kalchschmidt, M. (2014). Customer pressure and innovativeness: Their role in sustainable supply chain management. Journal of Purchasing and Supply Management, 20(2), 92-103.

Gunasekaran, A., Subramanian, N., \& Rahman, S. (2013). Special issue on green supply chain collaboration and Incentives. Transportation Research Part E: Logistics and Transportation Review. Available on http://www.journals.elsevier.com/transportation-research-part-e-logistics-and-transportation-review/calls-for-papers/green-supplychain-collaboration-and-incentives/. Accessed on May 2013.

Hair, J. F., Ringle, C. M., \& Sarstedt, M. (2011). PLS-SEM: Indeed a silver bullet. The Journal of Marketing Theory and Practice, 19(2), 139-152.

Hall, J. (2001). Environmental supply-chain innovation. Greener Management International, 2001(35), 105-119.

Handfield, R. B., Walton, S. V., Seegers, L. K., \& Melnyk, S. A. (1997). 'Green'value chain practices in the furniture industry. Journal of Operations Management, 15(4), 293-315.

Handfield, R., Sroufe, R., \& Walton, S. (2005). Integrating environmental management and supply chain strategies. Business Strategy and the Environment, 14(1), 1-19.

Hillman, A. J., Withers, M. C., \& Collins, B. J. (2009). Resource dependence theory: a review. Journal of Management, 35(6) 1404-1427.

Hoejmose, S., Brammer, S., \& Millington, A. (2012). “Green” supply chain management: The role of trust and top management in B2B and B2C markets. Industrial Marketing Management, 41(4), 609-620.

Hsu, C. W., \& Hu, A. H. (2008). Green supply chain management in the electronic industry. International Journal of Environmental Science \& Technology, 5(2), 205-216.

ISO. Environmental management systems - requirements with guidance for use (ISO 14001:2004); 2004.

Jabbour, C. J. C., \& Jabbour, A. B. L. D. S. (2014). Latin America: research opportunities on management for sustainable development. Latin American Journal of Management for Sustainable Development, 1(1), 1-6.

Jänicke, M. (2008). Ecological modernisation: new perspectives. Journal of Cleaner Production, 16(5), 557-565.

Jay, M., \& Morad, M. (2007). Crying over spilt milk: A critical assessment of the ecological modernization of New Zealand's dairy industry. Society and Natural Resources, 20(5), 469-478.

Jick, T. D. (1979). Mixing qualitative and quantitative methods: Triangulation in action. Administrative science quarterly, 24(4), 602-611.

Junquera, B., del Brío, J. Á., \& Fernández, E. (2012). Clients' involvement in environmental issues and organizational performance in businesses: an empirical analysis. Journal of Cleaner Production, 37, 288-298.

Kim, B., Park, K., \& Swink, M. (2014). Consumers' preferences for facets of green supply chain management. International Journal of Services and Operations Management, 18(1), 74-98.

Kock, N. (2015). Common method bias in PLS-SEM: A full collinearity assessment approach. International Journal of eCollaboration, 11(4), 1-10.

Kumar, S., Luthra, S., \& Haleem, A. (2014). Critical success factors of customer involvement in greening the supply chain: an empirical study. International Journal of Logistics Systems and Management, 19(3), 283-310.

Lai, K. H., Wong, C. W., \& Cheng, T. C. E. (2012). Ecological modernisation of Chinese export manufacturing via green logistics management and its regional implications. Technological Forecasting and Social Change, 79(4), 766-770.

Lai, K. H., Wong, C. W., \& Venus Lun, Y. H. (2014). The role of customer integration in extended producer responsibility: A study of Chinese export manufacturers. International Journal of Production Economics, 147, 284-293.

Langley, A. (1999). Strategies for theorizing from process data. Academy of Management Review, 24, 691-710

Laosirihongthong, T., Adebanjo, D., \& Tan, K. C. (2013). Green supply chain management practices and performance. Industrial Management \& Data Systems, 113(8), 1088-1109.

Mesquita, L., \& Lazzarini, S. G. (2008). Horizontal and vertical relationships in developing economies: Implications for SME access to global markets. Academy of Management Journal, 51, 359-380

Miles, M. R., \& Huberman, A. M. (1994). Qualitative Data Analysis: An expanded source book, Thousand Oaks: Sage 
Min, H., \& Galle, W. P. (2001). Green purchasing practices of US firms. International Journal of Operations \& Production Management, 21(9), 1222-1238.

Mitra, S., \& Datta, P. P. (2014). Adoption of green supply chain management practices and their impact on performance: an exploratory study of Indian manufacturing firms. International Journal of Production Research, 52(7), $2085-2107$.

Modell, S. (2005). Triangulation between case study and survey methods in management accounting research: An assessment of validity implications. Management accounting research, 16(2), 231-254.

Mol, A. P. (2000). Ecological modernization: industrial. The International Yearbook of Environmental and Resource Economics, 2000/2001, 138.

Murillo-Luna, J. L., Garcés-Ayerbe, C., \& Rivera-Torres, P. (2011). Barriers to the adoption of proactive environmental strategies. Journal of Cleaner Production, 19(13), 1417-1425.

Murphy, J., \& Gouldson, A. (2000). Environmental policy and industrial innovation: integrating environment and economy through ecological modernisation. Geoforum, 31(1), 33-44.

National Geographic (2016). Greendex: Consumer choice and environment a worldwide tracking survey. Available in: http://environment.nationalgeographic.com/environment/greendex/ Accessed on July of 2016.

Nawrocka, D. (2008). Inter-organizational use of EMSs in supply chain management: some experiences from Poland and Sweden. Corporate Social Responsibility and Environmental Management, 15(5), 260-269.

Nawrocka, D., Brorson, T., \& Lindhqvist, T. (2009). ISO 14001 in environmental supply chain practices. Journal of Cleaner Production, 17(16), 1435-1443.

Nouira, I., Hammami, R., Frein, Y., \& Temponi, C. (2016). Design of forward supply chains: Impact of a carbon emissionssensitive demand. International Journal of Production Economics, 173, 80-98.

Park, J., Sarkis, J., \& Wu, Z. (2010). Creating integrated business and environmental value within the context of China's circular economy and ecological modernization. Journal of Cleaner Production, 18(15), 1494-1501.

Paulraj, A., \& Chen, I. J. (2007). Environmental uncertainty and strategic supply management: a resource dependence perspective and performance implications. Journal of Supply Chain Management, 43(3), 29-42.

Pereira-Moliner, J., Claver-Cortés, E., Molina-Azorín, J. F., \& José Tarí, J. (2012). Quality management, environmental management and firm performance: direct and mediating effects in the hotel industry. Journal of Cleaner Production, 37, 82-92.

Pfeffer, J., \& Salancick, G. (1978). The External Control of Organizations, A Resource Dependence Perspective, New York: Harper \& Row Publishers.

Ramanathan, U., \& Gunasekaran, A. (2014). Supply chain collaboration: Impact of success in long-term partnerships. International Journal of Production Economics, 147, 252-259.

Ramanathan, U., Bentley, Y., \& Pang, G. (2014). The role of collaboration in the UK green supply chains: an exploratory study of the perspectives of suppliers, logistics and retailers. Journal of Cleaner Production, 70, 231-241.

Ringle, C. M., Sarstedt, M., \& Straub, D. W. (2012). Editor's comments: a critical look at the use of PLS-SEM in MIS quarterly. MIS Quarterly, 36(1), iii-xiv.

Ringle, C.M., Wende, S., \& Will, A. (2005). Smart PLS 2.0 M3. University of Hamburg.

Sarkis, J., \& Rasheed, A. (1995). Greening the manufacturing function. Business Horizons, 38(5), 17-27.

Sarkis, J., Zhu, Q., \& Lai, K. H. (2011). An organizational theoretic review of green supply chain management literature. International Journal of Production Economics, 130(1), 1-15.

Schnittfeld, N. L., \& Busch, T. (2015). Sustainability Management within Supply Chains-A Resource Dependence View. Business Strategy and the Environment, in press.

Schoenherr, T., Modi, S. B., Talluri, S., \& Hult, G. T. M. (2014). Antecedents and Performance Outcomes of Strategic Environmental Sourcing: An Investigation of Resource-Based Process and Contingency Effects. Journal of Business Logistics, 35(3), 172-190.

Sieber, S. D. (1973). The integration of fieldwork and survey methods. American journal of sociology, 1335-1359.

Tate, W. L., Ellram, L. M., \& Dooley, K. J. (2014). The impact of transaction costs and institutional pressure on supplier environmental practices. International Journal of Physical Distribution \& Logistics Management, 44(5), 353-372.

Ulrich, D., \& Barney, J. B. (1984). Perspectives in organizations: resource dependence, efficiency, and population. Academy of Management Review, 9(3), 471-481.

Vachon, S., \& Klassen, R. D. (2006). Extending green practices across the supply chain: the impact of upstream and downstream integration. International Journal of Operations \& Production Management, 26(7), 795-821. 
Vachon, S., \& Klassen, R. D. (2008). Environmental management and manufacturing performance: the role of collaboration in the supply chain. International Journal of Production Economics, 111(2), 299-315.

Vazquez-Brust, D., Smith, A. M., \& Sarkis, J. (2014). Managing the transition to critical green growth: The 'Green Growth State'. Futures, 64, 38-50.

Walker, H., \& Jones, N. (2012). Sustainable supply chain management across the UK private sector. Supply Chain Management: An International Journal, 17(1), 15-28.

Walton, S. V., Handfield, R. B., \& Melnyk, S. A. (1998). The green supply chain: integrating suppliers into environmental management processes. International Journal of Purchasing and Materials Management, 34(1), 2-11.

Wolf, J. (2014). The relationship between sustainable supply chain management, stakeholder pressure and corporate sustainability performance. Journal of Business Ethics, 119(3), 317-328.

Woo, C., Kim, M. G., Chung, Y., \& Rho, J. J. (2016). Suppliers' communication capability and external green integration for green and financial performance in Korean construction industry. Journal of Cleaner Production, 112, 483-493.

Yang, C. S., Lu, C. S., Haider, J. J., \& Marlow, P. B. (2013). The effect of green supply chain management on green performance and firm competitiveness in the context of container shipping in Taiwan. Transportation Research Part E: Logistics and Transportation Review, 55, 55-73.

Yin, R. K. (1984). Case study research: design and methods (2sd ed). Michigan: Sage.

York, R., \& Rosa, E. A. (2003). Key challenges to ecological modernization theory institutional efficacy, case study evidence, units of analysis, and the pace of eco-efficiency. Organization \& Environment, 16(3), 273-288.

Youn, S., Yang, M. G. M., Hong, P., \& Park, K. (2013). Strategic supply chain partnership, environmental supply chain management practices, and performance outcomes: an empirical study of Korean firms. Journal of Cleaner Production, 56, 121130 .

Zailani, S., Jeyaraman, K., Vengadasan, G., \& Premkumar, R. (2012). Sustainable supply chain management (SSCM) in Malaysia: A survey. International Journal of Production Economics, 140(1), 330-340.

Zhu, Q., \& Sarkis, J. (2004). Relationships between operational practices and performance among early adopters of green supply chain management practices in Chinese manufacturing enterprises. Journal of Operations Management, 22(3), 265-289.

Zhu, Q., Sarkis, J., \& Geng, Y. (2005). Green supply chain management in China: pressures, practices and performance. International Journal of Operations \& Production Management, 25(5), 449-468.

Zhu, Q., Sarkis, J., \& Lai, K. H. (2008). Confirmation of a measurement model for green supply chain management practices implementation. International Journal of Production Economics, 111(2), 261-273.

Zhu, Q., Sarkis, J., \& Lai, K. H. (2012). Examining the effects of green supply chain management practices and their mediations on performance improvements. International Journal of Production Research, 50(5), 1377-1394.

Zhu, Q., Sarkis, J., Lai, K. H., \& Geng, Y. (2008). The role of organizational size in the adoption of green supply chain management practices in China. Corporate Social Responsibility and Environmental Management, 15(6), $322-337$. 